\title{
PROSTOR OD ALPA I JADRANA DO DUNAVA I NERETVE U SVJETLU MATERIJALNIH TRAGOVA INZULARNE UMJETNOSTI KAROLINŠKOG DOBA*
}

\begin{abstract}
Epizoda s nalazima otočne irske, anglosaksonske ili općenito hiberno-karolinške umjetnosti, koja predstavlja specifičnu temu unutar kulturne povijesti ranoga srednjeg vijeka Europe, povezanu s misionarskom djelatnošću, nije mogla mimoići ni prostore od Alpa i Jadrana do Neretve i Dunava, posebice ne u povijesnim trenutcima koji su prethodili Aachenskom miru 812. godine između franačkog cara Karla Velikog (768. - 814.) i bizantskog cara Mihajla I. Rangabe (811. - 813.).

Ključne riječi: Aachenski mir; Karlo Veliki; Pipin; Franci; Avari; Salzburg; Akvileja; Paulin II.; irska misionarska djelatnost; nalazi otočnog umjetničkog obrta.

* Napomena: Rukopis je predan 2013. godine u tisak organizatorima znanstvenog skupa Hrvatska arheologija i Aachenski mir 812. - 2012., održanog u Zadru 2012. godine u organizaciji Arheološkog muzeja u Zagrebu, Odsjeka za arheologiju Sveučilišta u Zagrebu i Odjela za arheologiju Sveučilišta u Zadru. Kako ni do 2019. godine rukopis nije objelodanjen, koristimo prigodu da ga u prerađenom i dopunjenom obliku realiziramo u časopisu RAD Razreda za društvene djelatnosti Hrvatske akademije znanosti i umjetnosti.
\end{abstract}

\section{UVODNE NAPOMENE}

Na temelju do sada poznatih i vrjednovanih malobrojnih te ponekih novijih materijalnih nalaza umjetničkog obrta s prostora obuhvaćenog naslovom u našem se prilogu tematizira specifična pojava fenomena inzularne irske, tj. otočne umjetnosti karolinške epohe. U početku je uopće teško pojmljiva činjenica da se s osebujnim tragovima umjetničkog stvaralaštva iz udaljenog sjevernog središta europske duhovnosti, s krajnjih „,atlantskih rubova Europe“, konkretno Irske, susrećemo čak na prostoru istočno od Alpa i istočne obale Jadrana. To su materijalni dokazi otočnog svijeta koji je - zahvaljujući irskim, ali i anglosaksonskim znanstvenicima i poglavito kršćanskim misionarima te ambicioznim nastojanjima Karla Velikog - oblikovao intelektualni život i drugih krajeva Europe. 
Kako bismo pojasnili izvornost otočnog kršćanstva, valja se, u nastavku, sažeto podsjetiti nekih činjenica koje pomažu pristupu našoj temi. U blizini rimskih Britanije i Galije, zahvaćenih kršćanstvom iz Rimskoga Carstva, u Irsku dolaze, isprva trgovačkim svezama, i prvi kršćanski utjecaji. Irska prelazi na kršćanstvo, u kojem nalazi utočište i pogodno tlo za širenje i prije sv. Patrika. Monaški je život u Irsku uveo sv. Patrik, čija je misija ondje potrajala u 5. stoljeću ${ }^{2}$ i dovela do procvata monaštva u 6 . stoljeću. ${ }^{3}$

Slijedeći mišljenje Egona Wamersa, inzularna misija prema kontinentu odvijala se u dva međusobno relativno udaljena neovisna pokreta koja je poticalo franačko vrhovništvo radi ubrzanja "frankizacije“ područja uz desnu obalu Rajne i Bavarske, a kasnije i Saksonije. ${ }^{4}$ Za nas je bitan irski samostanski pokret od kasnog 6. do sredine 8. stoljeća, a u znatno manjoj mjeri ciljana misija Anglosaksonaca od kasnog 7. do kasnog 9. stoljeća. Misija Anglosaksonaca bila je djelatna više u sjevernim dijelovima Franačke.

Prvi monasi već su tijekom 6. stoljeća napustili Irsku da kao hodočasnici potraže osamljena mjesta radi neposrednog susreta s Bogom. ${ }^{5}$ Misija Kolumbana Mlađeg (590. - 615.) potaknula je veliko razdoblje irske monaške ekspanzije u inozemstvo. Konkretno, ta je ekspanzija irskih redovnika dovela do postanka brojnih samostana diljem Francuske, posebice onih u Burgundiji, potom u alpskom prostoru Švicarske, Austrije i sjeverne Italije te u Belgiji i Njemačkoj. ${ }^{6} \mathrm{Na}$ navedenim su prostorima udomaćili bogatu samostansku kulturu irskog izraza s njegovanjem duhovnih i umjetničkih Božjih djela. ${ }^{7}$ Posebno je važno veliko misionarsko putovanje sv. Kolumbana od Luxeuila u Burgundiji duž Rajne do Švicarske, pa preko Bodenskog jezera do Bregenza u Austriji te na jug preko Alpi i sjeverne Italije sve do Bobbija, gdje je 613. godine osnovao svoj posljednji samostan. ${ }^{8}$ U samostanima u Bobbiju i u Sv. Galu nastale su važne knjižnice. U Sv. Galu knjižnicu je osnovao Kolumbanov učenik. Središta irskoga kršćanskog utjecaja bila su kako u zapadnoalpskom prostoru (St. Gallen, Rheinau, Reichenau, Chur, Lindau, Müstair), tako i istočnije (Salzburg, Kremsmünster).

\footnotetext{
$1 \quad$ Irski su kršćani 431. godine dobili biskupa imenovanog iz Rima. To indirektno dokazuje brojnost kršćana u Irskoj, u kojoj su utočište pred barbarskim upadima u Rimsko Carstvo potražili i neki znanstvenici iz Galije (O FIACH 2003, 41).

2 Misija sv. Patrika u Irskoj započela je u drugoj ili trećoj četvrtini 5. stoljeća i trajala je oko trideset godina, tj. vjerojatno 432. - 461. ili 456. - 490. godine (Ó FIAICH 2003, 44).

3 Ó FIAICH 2003, 45.

4 WAMERS 1999, 453.

5 Ó FIAICH 2003, 51.

6 Ó FIAICH 2003, 52; WAMERS 1999, 453.

7 WAMERS 1999, 453.

8 Ó FIAICH 2003, 52.
} 
Na ozemlju Salzburga, tj. vojvodstva pod vlašću bavarskih Agilolfinga, pojavio se rani irski monaški utjecaj iz sjeverne Italije (Bobbio, Lucca, Fiesole). Važno središte irske misije postao je Salzburg, gdje je Irac po imenu Fergil, nama poznatiji kao Virgil, bio opat i biskup, a popis osoba, živih i mrtvih, za koje se tamošnja kršćanska zajednica molila uključivao je i opate starog irskog samostana Ione, još od doba njegova osnivača Columna Cillea, pa sve do petnaestog opata, Fergilova suvremenika. ${ }^{9}$

Stapanje irske i latinske kulture najjasnije se može vidjeti u irskoj umjetnosti 7. i 8. stoljeća. ${ }^{10}$ Irski su kovači svoje prastare vještine koristili kako bi slavili kršćansku crkvu. Irci su odlazili u hodočašća, „tražeći spasenje i samoću“, ali su i pokrštavali poganske narode, gradili knjižnice na kontinentu, pisali znanstvena djela te pomogli pripremiti teren za procvat znanja do kojeg će u 9. stoljeću doći u Franačkom Carstvu. ${ }^{11}$ Pritom valja razlikovati između misije u poganskom okruženju i evangelizacije unutar pretpostavljenog kršćanskog svijeta. ${ }^{12}$

Francima, posebice Karolinzima, tijekom njihovih ekspanzija moći, posebice u Bavarsku, koje su u zapadnoalpskom području uključivale važne prijevoje prema pripojenim karantanskim Slavenima, ubrzo je postalo jasno da stvarno i unutarnje uključivanje istočnih zemalja u njihovu vlast može biti ostvareno samo pojačanom misijom i crkvenom organizacijom, stoga su pozdravili i poticali misionarsku djelatnost pobožnih i školovanih ljudi koji su dolazili neposredno iz daleke Irske, a potom pojačano i iz susjedne Anglije u sjevernu Franačku. ${ }^{13}$

U temeljitom prikazu pojasne garniture iz Mogorjela koju je Werner, po visokoj kvaliteti animalnog ukrasa, uvrstio među najbolje profane kovinske tvorevine tzv. inzularnog stila ranokarolinškog horizonta druge polovine 8. stoljeća, kartirao je tu vrstu nalaza od Frizije i saksonske obale Sjevernoga mora, Porajnja, Tiringije i južne Njemačke do srednje Italije, koja je tada bila pod franačkom vlašću. ${ }^{14}$

U Franačkom Kraljevstvu, sjeverno od Alpa, očuvali su se, osim knjiga koje su stvorili irski i anglosaksonski pisci i iluminatori, i poneki malobrojni istaknutiji uradci umjetnika kovača - zlatara iz druge polovine 8. stoljeća, koji su bili neposredno djela inzularne umjetnosti. Njima Werner i Wamers pridružuju tzv. Rupertov križ iz Bischofshofena, Tassilov kalež iz Kremsmünstera i Starije korice

\footnotetext{
HUGHES 2003, 63.

10 HUGHES 2003, 61.

11 HUGHES 2003, 66.

12 WOOD 2002, 167, bilj. 2.

13 WAMERS 1999, 458.

14 WERNER 1961, 240, sl.(Abb.) 4.
} 
knjige iz Lindaua. ${ }^{15} \mathrm{~S}$ tim istaknutim zlatarskim djelima mogu se stilski dovesti u svezu i određeni kovinski arheološki nalazi maloga formata, koji su naknadno otkriveni. Stilu Tassilova kaleža pridružuju se i ti jednostavni slučajni kovinski nalazi karolinškog oružja i opreme jahača, kao i ukrasni predmeti ${ }^{16}$.

Položaji nalaza kovinskih i klesarskih djela visokoga ranga, koja nose obilježja animalnog stila, pokazuju da se isti koncentriraju u alpskom prostoru i tvore svojevrsni umjetnički krajobraz u kojem je inzularni element imao važnu ulogu. Međutim, u odnosu na starije antičke i italske utjecaje, inzularni element imao je donekle sporednu ulogu. ${ }^{17}$

Čitav se kulturni krug obilježavao ili kao „inzularni stil kontinentalnog kovanja" ili prostorno ograničen na glavna sakralna djela i važne rukopise kao „inzularna kulturna provincija sa središtem u Salzburgu“, tj. „inzularna kulturna provincija" u Carstvu Karla Velikog..$^{18}$ Za ranije navedena vrhunska ostvarenja kovinske umjetnosti koja se skupno pripisuju tzv. stilu Tassilova kaleža istraživanja V. Elberna dovela su do spoznaje da toj skupini umjetničkoobrtnih tvorevina treba podrijetlo tražiti u Salzburgu i dovesti ga u neposrednu svezu s djelovanjem Irca Virgila (Fergal), koji je 745./746. bio opat samostana sv. Petra, a u razdoblju 749. - 784. nadbiskup Salzburga. ${ }^{19}$

Na djelima koja se pripisuju stilu Tassilova kaleža prepoznaju se, prema nadahnutim, nezaobilaznim i sažetim mislima Rosamund McKitterick, vrsne poznavateljice srednjovjekovne povijesti i profesorice na Sveučilištu u Cambridgeu, slojevitost kulturnog nasljeđa Europe i uloga Karla Velikog, koji je pridonio procvatu te multikulturne baštine oblikujući njezinu novu fizionomiju. ${ }^{20}$

Nakon prethodnog, nužno potrebnog prikaza širenja i rasprostiranja otočne misionarske djelatnosti i prepoznavanja kulturnog krajobraza „tzv. inzularne umjetničke provincije u Salzburgu", odnosno umjetničkoobrtnih uradaka u stilu Tasssilova kaleža tijekom vladavine Karla Velikog, okrećemo se povijesnoj sceni istočnoga dijela Europe potkraj 8. stoljeća.

\footnotetext{
15 WERNER 1961, 240, sl(Abb.) 4; WAMERS 1999, 460.

16 WAMERS 1999, 460-461.

17 WAMERS 1999, 461.

18 WAMERS 1999, 461.

19 ELBERN 1989.
}

20 „Osmo stoljeće u zapadnoj Europi bilo je doba novoga razvoja, ekspanzije kršćanstva i svježih početaka. Bilo je to razdoblje izvanrednog procvata kulture, posebice $\mathrm{u}$ franačkoj sferi. Ta se kultura sigurno temeljila na intelektualnim i kulturnim postignućima prethodna četiriju stoljeća, kao i na baštini rimskoga svijeta. Usprkos tome, u Franačkom Kraljevstvu, od 780-ih nadalje, pokazuje se da je vrlo važan poticaj bio uvjetovan samim vladarom, Karlom Velikim.“ (McKITTERICK 2005, 151) 
Naime, uključivanjem otprije poznatih i analiziranih nalaza s obilježjima inzularnog karaktera, kao i ponekog slučajnog, u novije doba pribavljenog primjerka, postupno se oblikuju ponešto širi pogledi na ishodišta, potencijalne nosioce i pravce širenja misionarske djelatnosti koji su dosegnuli istočne zone osvajanja i utjecaja cara Karla Velikog. Na taj se način vrlo jasnim materijalnim tragovima i dokazima prostor od Alpa i Jadrana do istočnih granica karolinške interesne sfere, tj. Dunava i Neretve, snažno integrira i afirmira kao nezaobilazan u razdoblju neposredno prije Aachenskog mira 812.

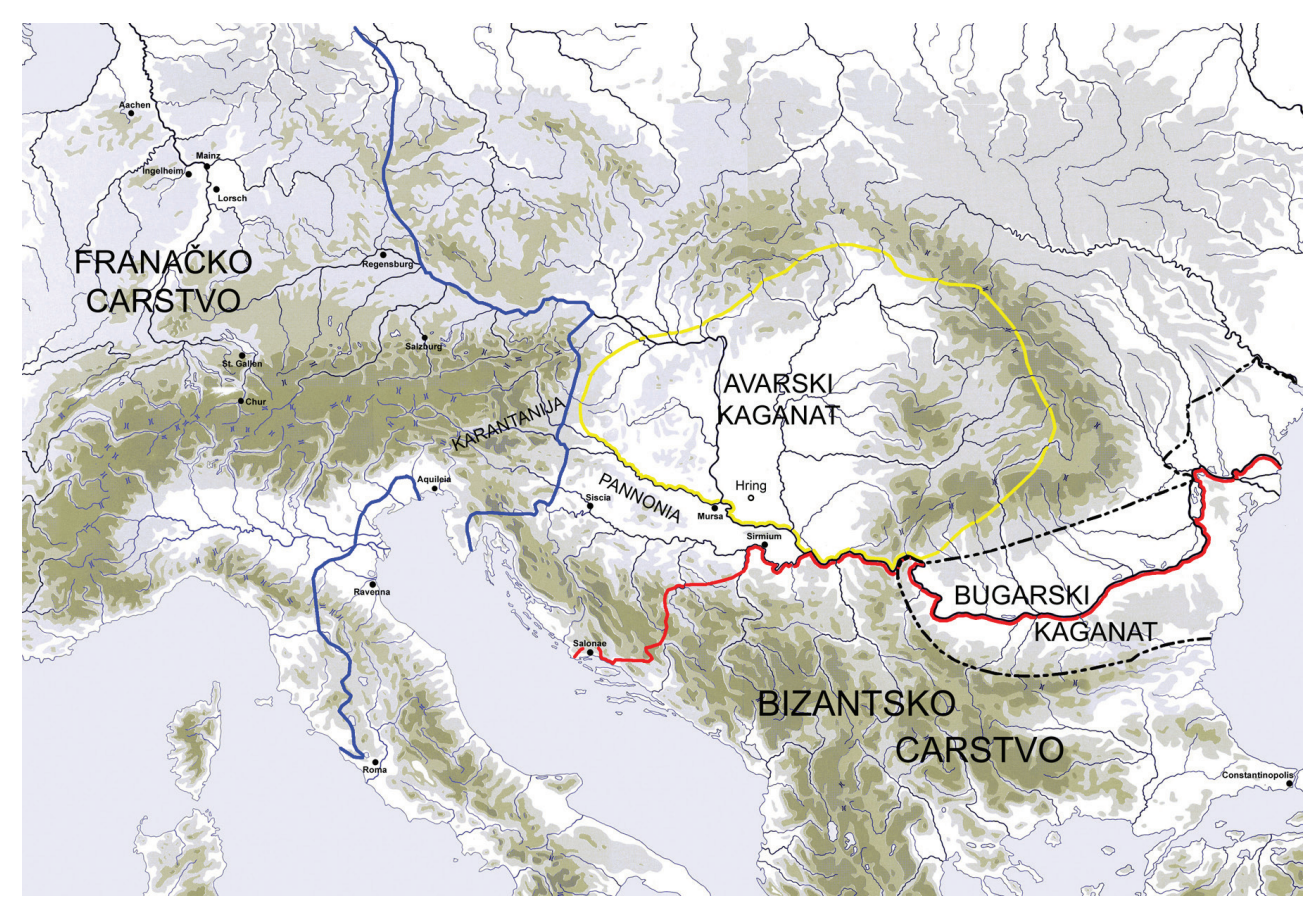

Slika 1. Zemljovid dijela srednjoeuropsko-mediteranskog prostora na prijelazu iz 8. u 9. stoljeće (osmislio autor - izradila Katarina Botić)

Valja nam se u početku ukratko podsjetiti ponekih povijesnih činjenica koje upotpunjuju smisao i poruku gore priloženog zemljovida. Ekspanzija Franačkog Kraljevstva usmjerila se 774. godine na pokoravanje Langobardskog Kraljevstva, 776. na pripojenje Furlanije do toka rijeke Soče, 780. na osvajanja sjevernog i središnjeg dijela Italije, potom 782. na ratovanje s Avarima i, što je posebice bitno za našu temu, do pripojenja vojvodstava Bavarske, Karantanije i Istre 788. godine. 
U doba bavarskog vojvode Tassila III. (748. - 788.) uslijedilo je, nakon pokoravanja Karantanije, misionarsko djelovanje i pristupanje tamošnjega slavenskog vladajućeg sloja kršćanstvu te je to područje 788. dočekalo dolazak vrhovništva Franaka.

$\mathrm{Na}$ taj je način Karlo Veliki stvorio de facto pomnjivo planiranu široku i pogodnu stratešku osnovicu za neizbježna nadolazeća odsudna ratovanja na istočnoj bojišnici s Avarskim Kaganatom. Država Avara u razdoblju 567. - 796. obuhvaćala je jezgru Karpatske kotline, tj. nekadašnje rimske provincije u Panoniji i njezina rubna područja na sjeveru i istoku, a na jugu krajnji istočni dio međurječja Drave, Dunava i Save.

Područje bivše rimske provincije Dalmacije bilo je samo formalno u sklopu Bizantskoga Carstva, koje je stvarnu vlast imalo u starim urbanim aglomeracijama istočnoga priobalja Jadrana i na pripadajućem arhipelagu.

U sjecištu preklapanja interesa tadašnjih europskih velesila oblikovao se, od Alpa i Jadrana do Dunava i Neretve, ranosrednjovjekovni prostor koji će 796. biti svjedokom urušavanja Avarskog Kaganata, potaknutog uspješnim prodorom italskog kralja Pipina, sina Karla Velikog. Na području od međurječja Drave, Dunava i Save na sjeveru do istočne jadranske obale na jugu u početcima političkog organiziranja oblikuju se na europsko-mediteranskom prostoru, ovisno o političkom djelovanju Franačkog i Bizantskog Carstva, dva prvobitna središta. ${ }^{21}$

U novije doba izneseni su u mađarskoj stručnoj literaturi vrlo zanimljivi stavovi o Pipinovu pohodu 796. na središte, tj. hring Avarskog Kaganata u Potisju, odnosno na održavanje važnog koncila na obalama Dunava te o Dunavu i propasti avarske države (slika 2). ${ }^{22}$

\footnotetext{
21 RAUKAR 1997, 24.

22 SZŐKE 2009, 93-112; SZŐKE 2011, 265-294.
} 


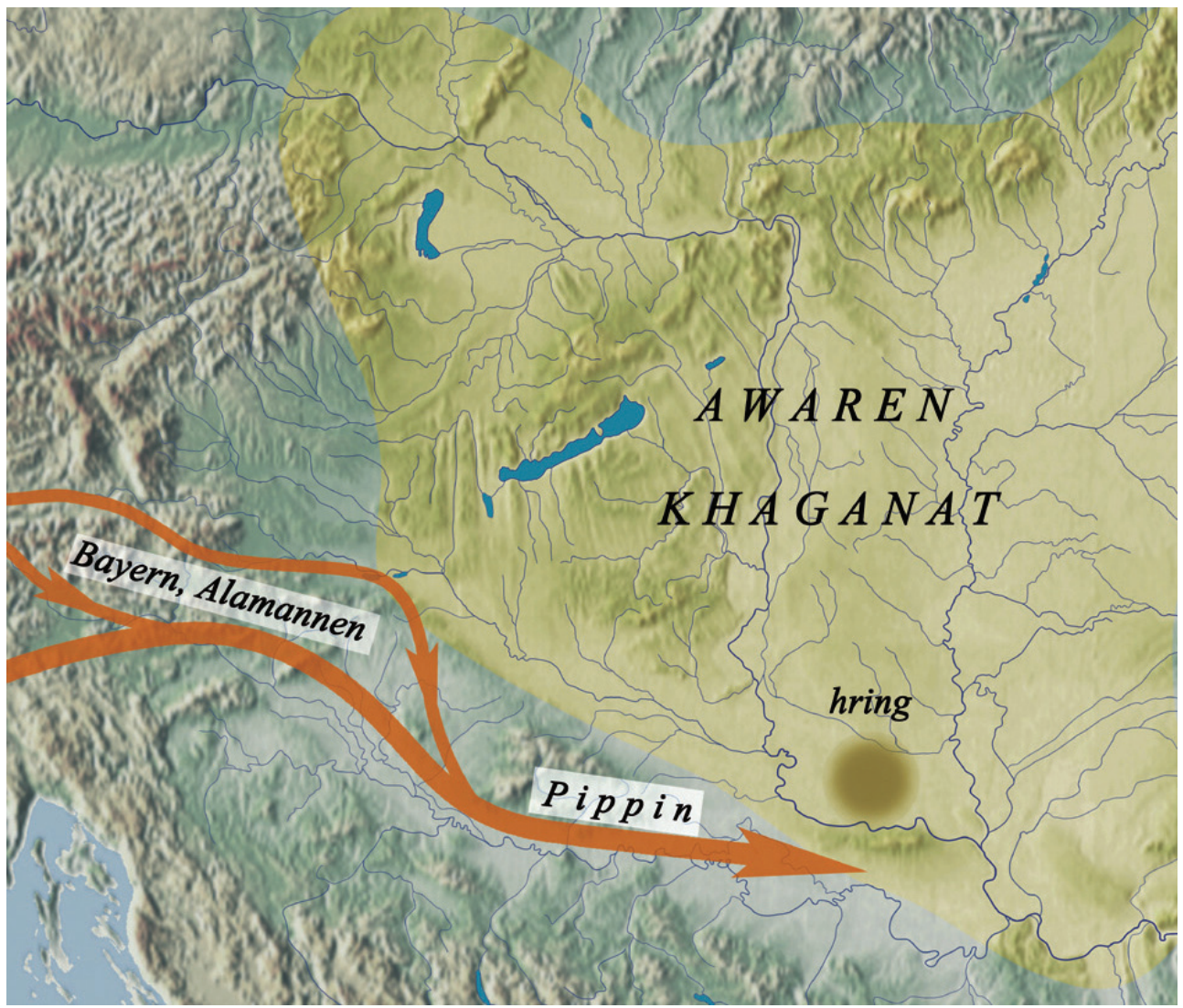

Slika 2. Pohod italskog kralja Pipina 796. na Avare (SZÖKE 2009)

Kao rezultat uspješnog okončanja ratova s Avarima, koji su de facto u Kaganatu prestali 803. godine, obavljena je, na inicijativu Karla Velikog 803. i potom 811. godine, podjela ogromnog novoosvojenog prostora, od Alpa na istoku te Dunava na sjeveru i istoku do Jadrana na jugu, između Salzburške nadbiskupije i Akvilejskog patrijarhata (slika 3). Prostor sjeverno od lijeve obale rijeke Drave do njezina ušća u Dunav pripao je Salzburškoj nadbiskupiji, dakle u to doba nadbiskupu Arnu, dok je sveukupan prostor od desne obale Drave do Jadrana pripao Akvilejskom patrijarhatu, tj. patrijarhu Paulinu II. 


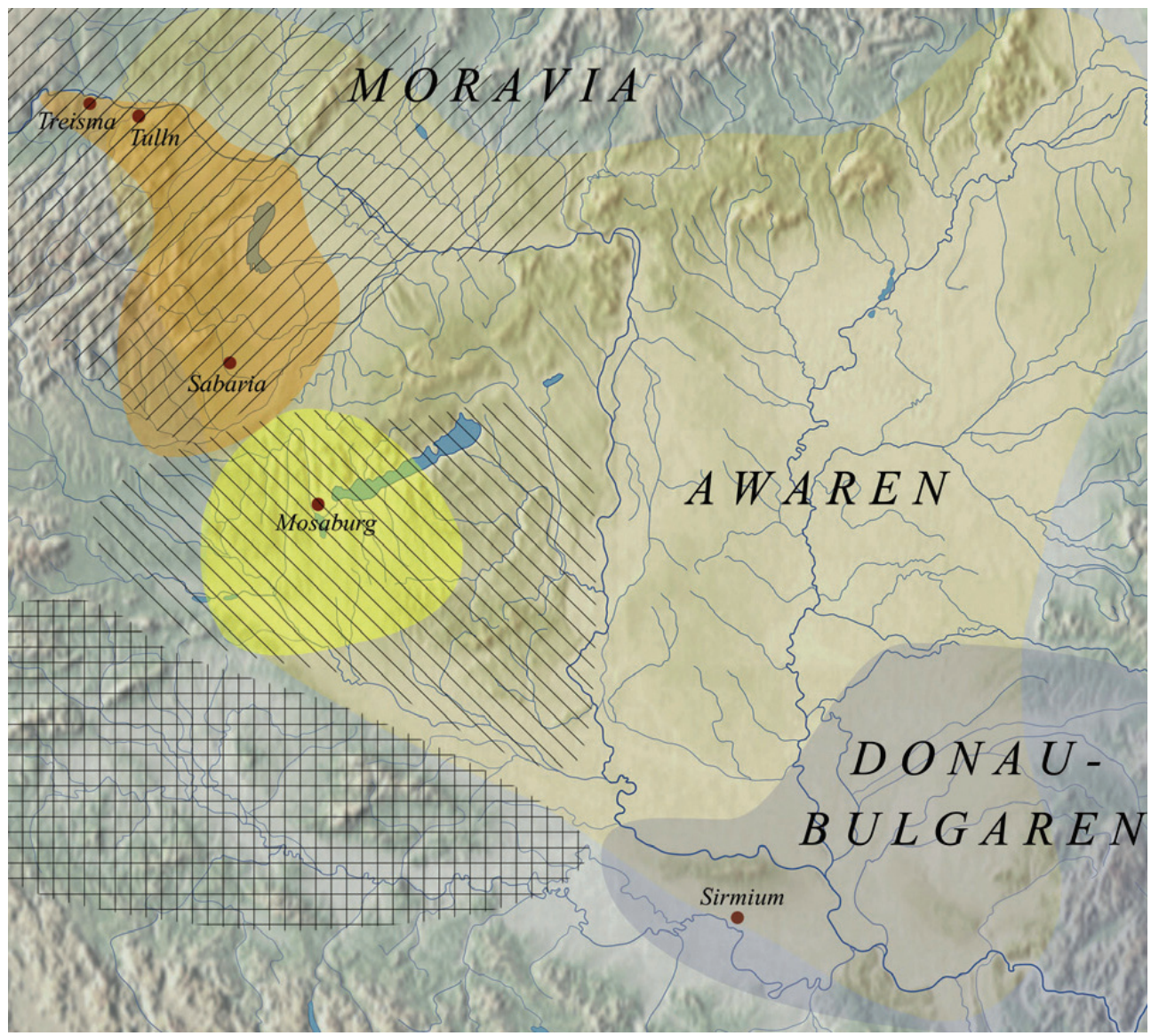

Slika 3. Zemljovid dijela Panonije s prikazom podjele crkvene vlasti između Salzburške nadbiskupije i Akvilejskog patrijarhata (SZÖKE 2009)

U nastavku ćemo se osvrnuti na registar materijalnih nalaza inzularnog, tj. hiberno-karolinškog umjetničkoobrtnog stvaralaštva koji se uklapaju u našu osnovnu temu. Ujedno ćemo ih pokušati povezati s irskom i donekle anglosaksonskom misionarskom djelatnošću i ekspanzijom Karolinga. Na tematskom zemljovidu (slika 4) navedeni su, promatrani od Alpa do istočne granice franačke ekspanzije, pojedinačni položaji nalaza inzularnog obilježja. 


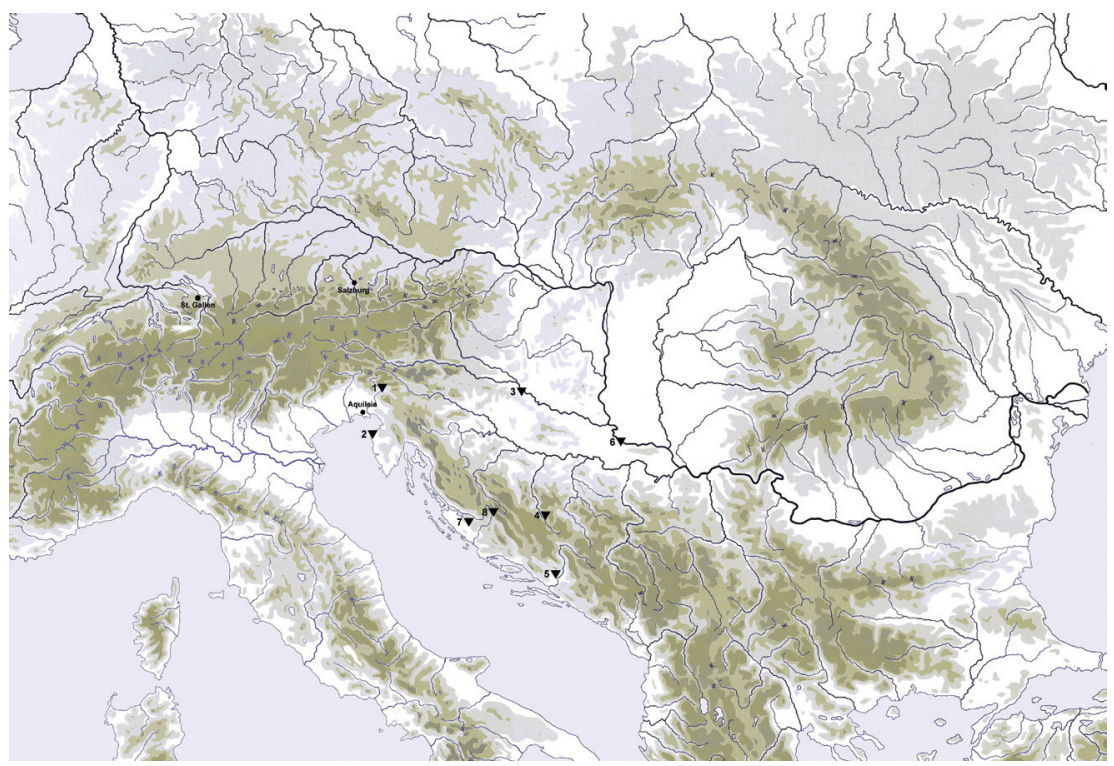

Slika 4. Zemljovid prostora od Alpa i Jadranskog mora do Dunava i Neretve s položajima nalaza inzularne umjetnosti u stilu Tassilova kaleža (osmislio autor - izradila Katarina BOTIĆ)

\section{PREGLED POKRETNIH NALAZA}

\section{Tonovcov grad}

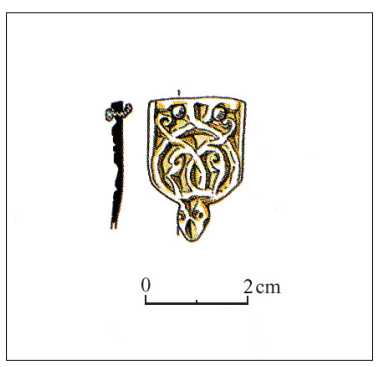

Slika 5. Tonovcov grad, pojasni jezičac, druga polovina 8. stoljeća (KNIFIC 2007)
Tonovcov grad kraj Kobarida jest kasnoantičko visinsko utvrđeno naselje u dolini Soče u zapadnoj Sloveniji koje dugotrajan kontinuitet života duguje prirodnoj prometnici, tj. strateški važnoj cesti koja vodi iz Furlanije u Korušku. ${ }^{23} \mathrm{~S}$ tog posebice znakovitog nalazišta, koje je niz godina uporno istraživao $S$. Ciglenečki, potječe i unikatni pozlaćeni slučajni nalaz lijevanog brončanog okova jezičca remena. ${ }^{24}$ Oblikom i po ukrasu pripada među karolinške uratke druge polovine 8 . stoljeća, tj. među predmete ukrašene inzularnom anglosaksonskom animalnom ornamentikom (slika 5). ${ }^{25}$

$\overline{23}$ CIGLENEČKI 1994, 6, T. 1,26; KNIFIC 2007, 324, sl. 2: 6; BITENC, KNIFIC 2001, 94, kat. 305.

24

KNIFIC 2007, 320, sl. 2,6, kat. 6, crtež D. Knific Lunder.

25 Donji rub jezičca oblikovan je u životinjsku glavicu. Na gornjem rubu uščuvane su bakrene zakovice vel. 2,5 x 1,6 cm, težina 4,06 g. Predmet je pohranjen u Kobaridskom muzeju u Kobaridu pod inv. br. 22492. 


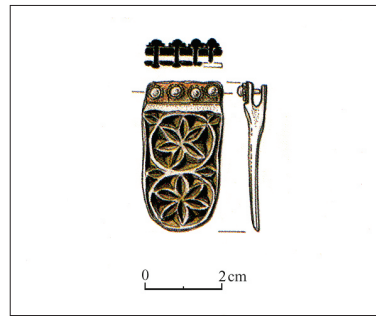

Slika 6. Gradišče nad Sotesko, pojasni jezičac ukrašen viticama i duboreznim palmetama (BITENC, KNIFIC 2001, 95, Nr. 313)

\section{Sipar}

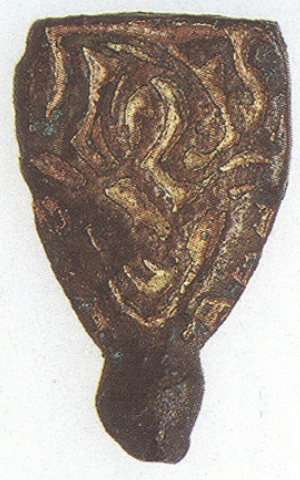

Slika 7. Sipar, pojasni jezičac ukrašen lozicom i životinskim ukrasom u stilu Tassilova kaleža (UJČIĆ 2000, 71, I. 61)
S položaja visinske utvrde zanimljivog i indikativnog naziva Gradišče nad Sotesko, sjeveroistočno od Tonovcova grada, potječe zanimljivi pozlaćeni brončani pojasni jezičac ukrašen viticama nalik slovu $S$ i duboreznim palmetama (slika 6), koji je stilski vrlo srodan nalazu iz Mogorjela kraj Čapljine. ${ }^{26} \mathrm{Na}$ taj se važni nalaz osvrnula i vrsna arheologinja europskoga ranog srednjovjekovlja Mechthild Schulze-Dörrlamm u opsežnoj studiji posvećenoj kovinskim izrađevinama s biljnim ukrasom i njihovim radioničkim središtima s područja Carstva Karla Velikog. ${ }^{27}$

Na istaknutom rtu koji se nalazi oko $4 \mathrm{~km}$ sjeverno od Umaga otkriveni su ostatci ranosrednjovjekovnog kaštela Sipar, koji se u ranosrednjovjekovnim zemljopisnim izvorima navodi pod različitim inačicama (lat. Sapparis, Sip(p)aris). S nepoznatog položaja i iz nepoznatog arheološkog konteksta na tom nalazištu potječe pojasni jezičac (slika 7), od pozlaćene bronce, dužine 2,8 cm i širine 1,7 cm. Predstavlja površinski nalaz iz 1985. godine. Ima završetak u obliku pupoljka. Lijevan je i ukrašen u tehnici rovašenja gustim prepletom krugolike lozice i životinjskim ukrasom u stilu Tassilova kaleža. Datira se na konac 8. stoljeća, a pohranjen je u Arheloškom muzeju Istre u Puli, inv. br. S 7539. ${ }^{28}$

$\overline{26}$ KNIFIC 1999, 67; BITENC, KNIFIC 2001, 95, Nr.313.

27 SCHULZE-DÖRRLAMM 2009, 776, Abb. 28, popis nalaza 26.

28 O tom nalazu postoji raspršena relevantna literatura: MARUŠIĆ et al. 1995, 113 (kat. Jed. 489. Sipar, pojasni jezičac); MARUŠIĆ 1973-1975, 9; UJČIĆ 2000, 2, kat.br. 71, I. 61.; MATIJAŠIĆ 2008, (Sipar, Istarska enciklopedija). 


\section{Medvedička}

Osobito dragocjen nalaz predstavlja inventar grobne cjeline ratnika odličnika otkriven u selu Medvedička u Podravini. ${ }^{29}$ Pojedinačni predmeti iz groba prikupljeni su u dva navrata, 1973. i 1977. godine. Među njima zapaženo mjesto pripada dvosjeklom maču, bojnoj sjekiri, nožiću i jezičcu pojasne garniture s inzularnim životinjskim ukrasom u stilu Tassilova kaleža ${ }^{30}$ Pojasni jezičac od pozlaćene je bronce, dužine $10,5 \mathrm{~cm}$ i širine $1,8 \mathrm{~cm}$. Pohranjen je u Arheološkome muzeju u Zagrebu (AMZ) pod inv. br. S-3095. Jednodijelan je, s obje strane ukrašen različito komponiranim motivima životinjskog prepleta anglokarolinškog, odnosno inzularnog stila izvedenim $u$ dubokom rovašenju. Na gornjem rascijepljenom dijelu jezičca tri su srebrne zakovice pomoću kojih se pričvršćivao na pojas, a ispod njih se nalazi pojas ukrašen motivom šrafiranih trokutića. ${ }^{31}$
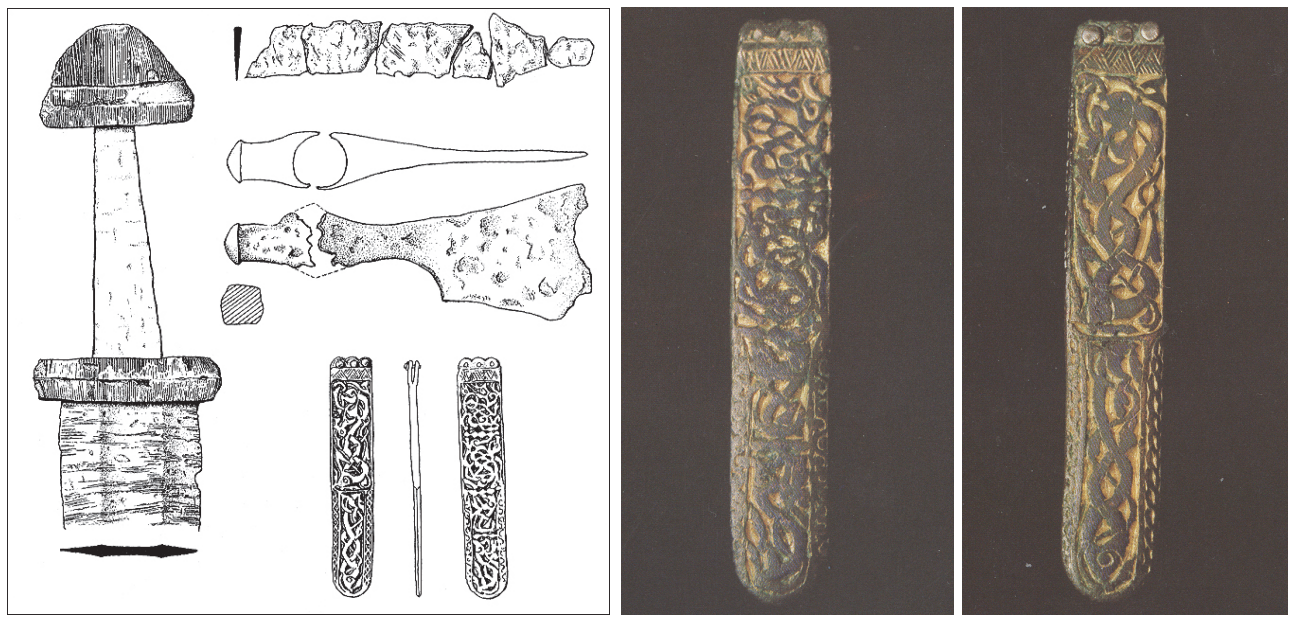

Slika 8. Medvedička, pojasni jezičac ukrašen u stilu Tassilova kaleža

(TOMIČı́́ 2000, 1, 153, slika 10)

Analogni primjerak pojasnog jezičca potječe iz kraljevske/carske rezidencije - aula regia u Ingelheimu. Primjerak je datiran u posljednju trećinu 8. stoljeća, odnosno u rano 9. stoljeće. ${ }^{32}$

\footnotetext{
29 VINSKI 1977/78, 143 i d., 166, T. X:1,2; T. XI.

30 SIMONI 2000, 2, kat. br. II. 15.

31 TOMIČIĆ 2000, 1, 153, sl. 10.

32 GREWE 1999, 465-466, katalog VII.26.
} 


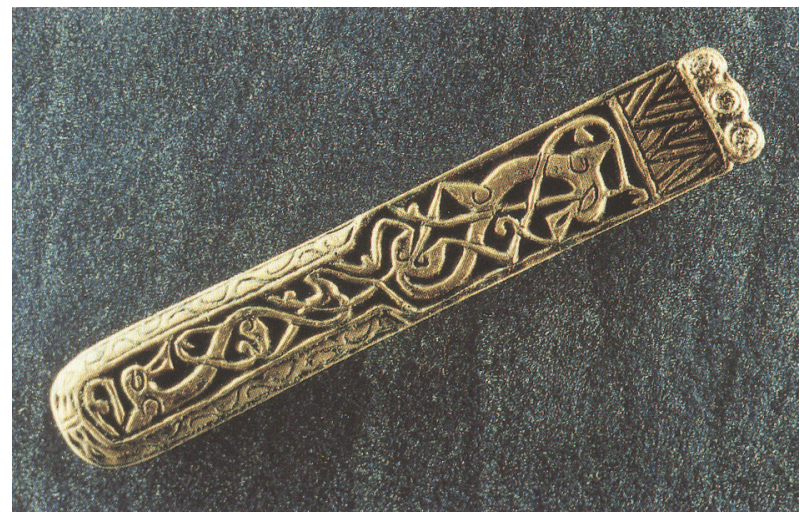

Slika 9. Ingelheim, pojasni jezičac ukrašen u stilu Tassilova kaleža (GREWE 1999)

Jezičac iz Ingelheima izrađen je od nekoć pozlaćene bronce, srebra i bakrenog lima i ima željezne zakovice. Dužine je $8,9 \mathrm{~cm}$, širine $1,5 \mathrm{~cm}$ te debljine 0,3 $\mathrm{cm} .{ }^{33}$ Završetak remena ima tri željezne zakovice. Prednja strana geometrijski je dekorirana, a u središnjem polju slike dviju figura životinja (zmija ili zmajeva) u tijesnom su prepletu traka i linija. Tijela su S-oblika, a glave s bademastim okom i trubljastim gubicama okrenute su unazad. Dugi rep ima razdvojeni rascijepljeni kraj. Ravnine prikaza obiju životinja nasuprotno su okrenute. Vanjski su uglovi uvučeni i nalik slovu „u“. Na obje strane jezičca motiv vitica završava u životinjskim glavama.

Između nalaza iz Ingelheima i pojasnog jezičca iz Waala kraj Rossuma (provincija Gelderland $u$ Nizozemskoj $)^{34}$ te našeg primjerka iz Medvedičke postoji vrlo uska oblikovna srodnost, premda je bitna razlika u kvaliteti izrade u korist primjerka iz Ingelheima. Svi su navedeni primjerci predstavnici stila Tassilova kaleža. ${ }^{35}$

\section{Gornji Vrbljani}

Utvrda nad rijekom Sanom kraj Gornjih Vrbljana pokraj Ključa u Bosni i Hercegovini, u kojoj je dokazana kulturna slojevitost tijekom kasne antike i ranoga srednjeg vijeka, nadzirala je $u$ antici staru rimsku prometnu vezu Panonije (Siscia) s Dalmacijom (Salona). Nakon Justinijanova kastrona iz 6. stoljeća izgra-

\footnotetext{
$\overline{33}$ Nalaz je pohranjen u Mainzu, u Zemaljskoj službi za zaštitu baštine u Odjelu arheološke zaštite spomeničke baštine (Inv. br. IH-K3-G475).

34 GREWE 1999, 465-466.

35 O jezičcu iz Ingelheima usporedi literaturu: Holger GREWE 1999, 465-466, Katalog VII. II.26 (799 Kunst und Kultur der Karolingerzeit. Karl der Große und Papst Leo III. in Paderborn, Band 2 Katalog der Ausstellung Paderborn 1999, 465-466, Katalog VII. II.26.
} 
đena je na istom položaju u ranom srednjem vijeku utvrda s karolinškom vojnom posadom koja je imala povremene sukobe, na što upućuju ondje pronađene trobridne avarske strelice. ${ }^{36}$ Iz karolinškodobne utvrde potječe nalaz unikatnog pojasnog jezičca (slike 10.a i 10.b). Ratnik kojem je pripadao jezičac očito je širio i čuvao kršćansku vjeru među poganskim pukom prije značajnijeg priključenja Franačkom Carstvu.

Potaknut promišljanjima niza autora koji su, nakon temeljite znanstvene objave Zdenka Vinskog, ${ }^{37}$ posvetili pažnju jedinstvenom ranokarolinškom pojasnom jezičcu iz Gornjih Vrbljana, i A. Milošević je, na temelju uvjerenja E. Wamersa da je spomenuti jezičac „izradio kovač Tetgis (franačko vlastito ime, npr. Tetgisus iz Reimsa iz 8. ili 9. stoljeća), u stilu Tassilovog kaleža u drugoj polovini 8. stoljeća, vjerojatno za nekog uglednika ili visokog vojnog časnika“, izrazio isti stav. ${ }^{38}$
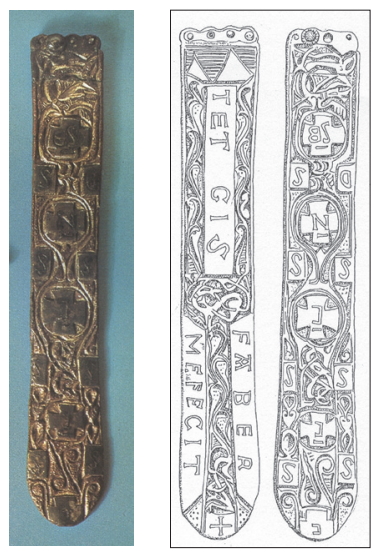

Slike 10.a i 10.b. Gornji Vrbljani, pojasni jezičac ukrašen u stilu Tassilova kaleža (VINSKI 1977-1978)

Pojasni jezičac datira se u posljednju četvrtinu 8 . stoljeća, izrađen je od pozlaćene bronce i srebra. Dužine je $16 \mathrm{~cm}$, širine 2,1-2,4 cm i debljine 0,4 cm. Pohranjen je u Zemaljskom muzeju Bosne i Hercegovine u Sarajevu pod priv. inv. br. 508.

$\mathrm{Na}$ primjerku ranokarolinškoga kovinskog jezičca iz Gornjih Vrbljana prepoznata je misionarska djelatnost, tj. epigrafička potvrda te pojave koja se javlja u trostrukom zazivu Sanctus, upisanom skraćenicama. Iz dalekog ishodišta u zapadnoj Franačkoj taj je uradak zlatara Tetgisa dosegnuo rubno područje hrvatske kneževine..$^{39}$ Duh Trojstva koji se razabire na jezičcu oznaka je prvoga vala karolinške vjerske ekspanzije, a ujedno i papinsko-karolinške koalicije na prostoru koji obuhvaća naš rad..$^{40}$ Posebice je važno da se na unikatnom pojasnom jezičcu vrlo jasno razabiru elementi ukrašavanja u stilu Tassilova kaleža. Naime, elementi ukrasa rovašene su, pozlaćene vitice i animalna ornamentika koji su vrlo vješto izvedeni na licu s votivnim tekstom, kao i na naličju s imenom zlatara Tetgisa. ${ }^{41}$

\footnotetext{
36 BOJANOVSKI 1974, GZMS n.s., 29/1974, 245-255; BOJANOVSKI 1979, GZMS n. s., 34/1979, 105-125.

37 VINSKI 1977-1978, VAMZX-XI, 144-149; VINSKI, 1985, bilj. 15., bilj. 16; VINSKI, 1974.; ZEKAN 1994, 68 ; WAMERS 1999, 463; MILOŠEVIĆ 2000, 2, 259, sl. IV. 132.

38 WAMERS 1999, 463; MILOŠEVIĆ 2000, 1, 2000, 114; MILOŠEVIĆ 2000, 2, 259, IV.132.

39

40 DELONGA 2000, 1, 243; DELONGA 2000, 2, kat.br.IV, 131.

DELONGA 2000, 1, 243.

41 MILOŠEVIĆ 2000, 259, kat. Br. IV. 132.
} 
Animalni ornament javlja se sam ili u kombinaciji s vegetabilnim elementima i predstavlja stiliziran, često skraćen prikaz starog mediteranskog motiva životinja na Drvetu života i blizak je anglosaksonskoj ornamentici prepletene vinove loze. ${ }^{42}$

\section{Mogorjelo - Čapljina}

Na nalaz ranokarolinške pojasne garniture iz tzv. kastela u Mogorjelu južno od Čapljine na Neretvi upozorio je prvi Joachim Werner nakon posjeta Zemaljskom muzeju u Sarajevu 1953. godine. ${ }^{43}$ U prostoru sjeveroistočne okrugle kule kastela Mogorjelo otkriveni su tijekom istraživanja koja je u razdoblju 1899. 1903. provodio Karlo Patsch karolinški okovi pojasa (slika 11: 1-2). ${ }^{44}$ Ujedno je u prostoriji, uz spomenutu okruglu sjeveroistočnu ugaonu kulu, otkriven i pojasni jezičac od pozlaćene bronce (slika 12). ${ }^{45}$
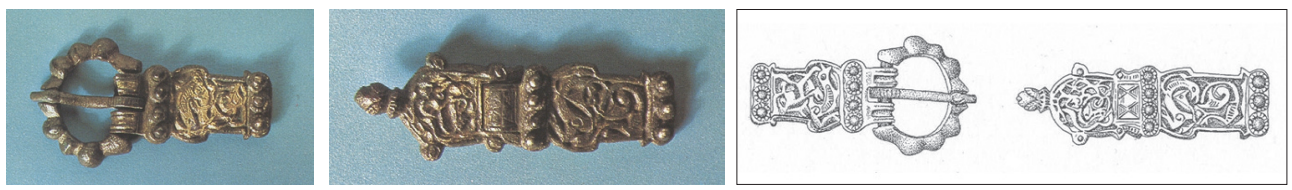

Slika 11: 1-2. Mogorjelo kraj Čapljine, ranokarolinška pojasna garnitura u stilu Tassilova kaleža (ZEKAN 1994)

Brončana pozlaćena pojasna garnitura s animalnim ornamentom (slika 11: 1-2) otkrivena 1903. godine u spomenutoj okrugloj sjeveroistočnoj kuli u Mogorjelu, prema uvjerenju J. Wernera, kvalitetom svojega životinjskog ukrasa predstavlja jedan od najboljih profanih kovinskih proizvoda u tzv. inzularnom stilu ranokarolinškog razdoblja. ${ }^{46}$ Vrlo detaljan opis spone, dužine $7 \mathrm{~cm}$ i dvočlanog okova pojasa dužine $8,2 \mathrm{~cm}$ i širine $2 \mathrm{~cm}$, a posebice pripadajući animalni rovašeni ukrasi taj nalaz uvjerljivo svrstavaju u drugu polovinu 8 . stoljeća. ${ }^{47}$ Slični primjeri opreme i nakita, poput okova pojasa, naušnica i narukvica, ostruga i pehara, koji se pojavljuju od Sjevernog mora preko južne Njemačke, a u manjoj mjeri i do srednje

\footnotetext{
$\overline{42}$ WAMERS 1999, 462-463, Abb. 12.

43 WERNER 1961, 238-240, sl. 2, 1-2, sl. 3, a i b. Položaj nalazišta u Mogorjelu uvrstio je i na karti rasprostiranja ranokarolinških kovinskih proizvoda u inzularnom stilu (vidi: WERNER 1961, 239, sl.(Abb) 4.).

44 PATSCH 1911, 15.

45 WERNER 1961, 237, sl. (Abb) 2:3.

46 WERNER 1961, 240.

47 WERNER 1961, 238, sl. (Abb) 3: a-b.
} 
Italije, dokazuju jak utjecaj anglo-irske misije iz 8. stoljeća na svjetovno umjetničko stvaranje u Karolinškom Carstvu. ${ }^{48}$ Ranokarolinška pojasna garnitura iz Mogorjela oblikom i ukrasima pripada krugu kovinskih umjetničkoobrtnih uradaka inzularnog stila nastalih sjeverno od Alpa, koja je u sjedište nekog gentilnog feudalca na Neretvi prispjela iz Furlanije i Istre te potom uzduž dalmatinske obale. ${ }^{49}$

Ranije spomenuti jezičac pojasa od pozlaćene bronce s pet okruglih srebrnih zakovica, koji je otkriven u prostoriji do sjeveroistočne okrugle ugaone kule kastela Mogorjelo (slika 12), na glatkoj donjoj strani ukrašen je pojednostavnjenim urezanim jelovim grančicama, dok je na licu s tragovima pozlate, $u$ dva četvrtasta polja, raspoređena po jedna osmerolatična rozeta koju iz uglova kvadrata podržavaju po dva listića. ${ }^{50}$ Prema Wernerovu mišljenju, u konturi pojasni jezičac iz Mogorjela pripada skupini srodnih primjeraka s područja Hrvatske, a općenito se može pripisati karolinškoj biljnoj ornamentici 9 . stoljeća. ${ }^{51}$

Analogiju s nalazom jezičca ukrašenim motivom rozeta iz Mogorjela kraj Čapljine u Hercegovini Knific pronalazi na Gradišču nad Sotesko u Alpama u ranije spomenutom pozlaćenom pojasnom jezičcu ${ }^{52}$ te ostrugama i dijelovima za njihovo povezivanje iz groba dječaka, otkrivenog u Biskupiji kraj Knina. $.^{53} \mathrm{Kni}-$ fic je dobro primijetio da su šesterolisnim rozetama u krugu ukrašeni i brojni kameni spomenici na ozemlju Kneževine Hrvatske, datirani većinom u drugu polovinu 8. i prvu polovinu 9. stoljeća. ${ }^{54}$
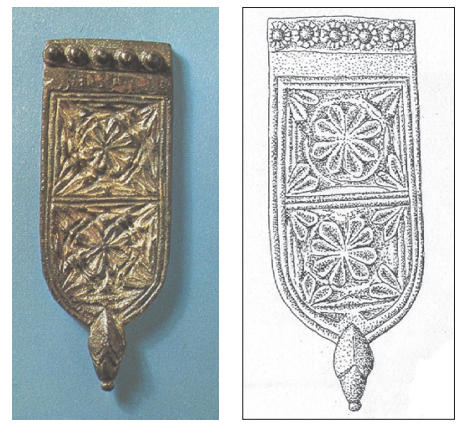

Slika 12. Mogorjelo kraj Čapljine, pojasni jezičac ukrašen motivom rozete (ZEKAN 1994)

\footnotetext{
48 WERNER 1959; WERNER 1961, 240.; HASELOFF 1951.

49

50

51

52

53

WERNER 1961, 240-241.

WERNER 1961, 237, sl. (Abb) 2. 3; MILETIĆ 1963, 54; ZEKAN 1994, 70; MILOŠEVIĆ 2000, 2, 283, kat. IV. 173.

WERNER 1961, 237, bilj. 9. i 10.

KNIFIC, 2007, 324, sl. 2,7.

JELOVINA, 1986, 24, T. 7, 82-89; 31; PETRINEC, 2000, 220-221, kat. IV.50, datacija: prva polovina 9. stoljeća.

54 KNIFIC 2007, 320.
} 
Pojasna garnitura iz Mogorjela oblikom i ukrasom nesumnjivo očituju pripadnost ranokarolinškom kulturnom krugu, s mogućim radioničkim ishodištem $\mathrm{u}$ alpskom prostoru u drugoj polovini 8. stoljeća. ${ }^{55} \mathrm{U}$ kastel na Neretvi pojasna garnitura vjerojatno nije dospjela, sudeći prema sličnim nalazima (Perugia, Ascoli), iz Italije već istočnojadranskim priobaljem, dakle kopnenim putem preko Istre i Dalmacije, svakako franačkim posredovanjem nakon propasti Langobardskog Kraljevstva i formiranja Furlanske marke. Nalazi iz Mogorjela dakle u taj kulturni krug ranokarolinškog svijeta svrstavaju i onodobne hrvatske prostore.

\section{Sotin - Popino brdo}

Na desnoj lesnoj povišenoj obali Dunava, unutar po nalazima izuzetno važnog arheološkog nalazišta u Sotinu (ant. Cornaccum), tijekom obilaska položaja Popino brdo, gdje je smještena župna crkva Uznesenja Blažene Djevice Marije, otkriven je bakreni pojasni jezičac s florealnim ukrasima i rupom od željezne uništene zakovice (slika 13). ${ }^{56}$ Pojasni jezičac s donje je strane gladak, a na gornjoj je strani ukrašen florealnim ukrasima, tj. vinovom lozom. Jezičac je dužine $4 \mathrm{~cm}$ i u gornjem dijelu širine $1,7 \mathrm{~cm}$. Težina jezičca nakon konzervatorskog zahvata iznosila je 10,2 g.

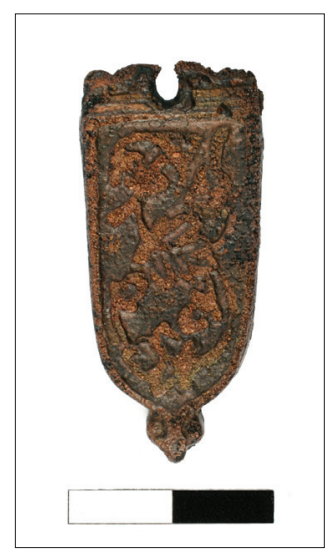

Slika 13. Sotin - Popino brdo, nalaz pojasnog jezičca (snimio Hrvoje JAMBREK)

WERNER 1961, 240.

56 Koristimo prigodu da najsrdačnije zahvalimo kolegi doc. dr. sc. Mati Ilkiću s Odjela za arheologiju Sveučilišta u Zadru na ustupanju prava na obavljivanje dragocjenoga ranokarolinškog nalaza, koji je osobno otkrio tridesetak metara ispred zapadnog pročelja župne crkve Uznesenja Blažene Djevice Marije u Sotinu.
} 
Proučavanje ranosrednjovjekovnog arheološkog nasljeđa na primjerima pokretnih nalaza dalo je jasne dokaze o dugotrajnom naseljavanju lesne zaravni ponad desne obale Dunava na položaju današnjeg Sotina. ${ }^{57}$ Podrobna analiza pokretnih nalaza s položaja nekadašnjeg antičkog kastela Cornacum dokazala je neprekinuti kontinuitet života od razdoblja velike seobe naroda do u epohu kasnog Avarskog Kaganata, tj. do prve polovine 8. i do početka 9. stoljeća. ${ }^{58}$ Posebice vrijedni nalazi iz kasnoavarskog doba svrstavaju Sotin u jedno od najznačajnijih nalazišta toga doba na području Hrvatske. Uglešić je s pravom naslutio da je Sotin (ant. Cornacum) imao u ranom srednjem vijeku vrlo važnu ulogu, posebice u razdoblju kasnog Avarskog Kaganata, i da se može uspoređivati s najznačajnijim nalazištima toga doba na području podunavskog limesa. Na tom se višeslojnom nalazištu konstantno pronalaze potvrde o ranom srednjem vijeku, ${ }^{59}$ među kojima u novije doba posebno mjesto pripada ranije navedenom pojasnom jezičcu iz Sotina koji možemo uvrstiti u ranokarolinški kulturni krug te za sada u najistočnije nalaze te vrste u međurječju Drave, Dunava i Save. Njegova je posebna odlika florealni ukras, tj. motiv vinove loze, koji ga približava tradicijama mediteranskog stvaralaštva.

Primjerak iz Sotina pokazuje veliku sličnost u ukrasnom motivu sa slučajnim nalazom srebrnog jezičca s plitkim reljefnim ukrasom vitice nalik slovu $S$ iz nekog nepoznatog nalazišta u Umbriji na Apeninskom poluotoku koji se datira u kasno 8. / rano 9. stoljeće. ${ }^{60} \mathrm{U}$ zapadnom sredozemnom prostoru javljaju se u karolinško doba kovinski nalazi s biljnim ukrasima do sada još nepoznate vrste. ${ }^{61}$

\section{Ostrovica (Mačkova glavica ?)}

Među izuzetno rijetke nalaze koje možemo pripisati ranokarolinškom kulturnom krugu na kojem se prepoznaje tradicija primjene florealnog ukrasa navodimo primjerak pojasnog jezičca iz zaleđa Zadra, točnije iz ranosrednjovjekovne Ostrovice (slika 14). Taj je pojasni jezičac na prednjoj strani, na kojoj su i zakovice, ukrašen biljnim ukrasima, tj. po našem uvjerenju motivom Drveta života (lat. Arbor vitae). To je stablo nosilac i simbol životne borbe, odnosno sta-

\footnotetext{
57 UGLEŠIĆ 1994, 145-152. Analiza pokretnih nalaza iz Sotina omogućena je ljubaznošću doc. dr. sc. Mate Ilkića, koji je velikom ljubavlju prema rodnom mjestu spasio brojnu i dragocjenu arheološku građu iz Sotina.

58 UGLEŠIĆ 1994, 152.

59 ILKIĆ 2007, 277-288.

60 SCHULZE-DÖRRLAMM 2009, 774, Abb. 31.

61 SCHULZE-DÖRRLAMM 2009, 774.
} 
rozavjetno stablo spoznanja dobra i zla iz raja zemaljskog. ${ }^{62}$ Mišljenja smo da na temelju ukrasnog motiva nalaz možemo pripisati mediteranskoj umjetničkoobrtnoj tradiciji, udomaćenoj zbog utjecaja iz Akvileje i u ranokarolinškom kulturnom krugu. Taj je utjecaj moguće dovesti u svezu s djelovanjem toga snažnog vjerskog središta u doba nakon franačkog osvajanja Istre 788. godine, a posebice misionarskim djelovanjem akvilejskog patrijarha Paulina II. nakon 796. godine, tj. pokorenja Avarskog Kaganata.

Pojasni jezičac pronašao je prije Domovinskog rata Ivica Ćurković iz Zadra te mu na ovome mjestu ljubazno zahvaljujemo na razumijevanju i pravu na objavljivanje. Dužina jezičca iz Ostrovice iznosi $3,5 \mathrm{~cm}$, a širina $1,4 \mathrm{~cm} .{ }^{63}$

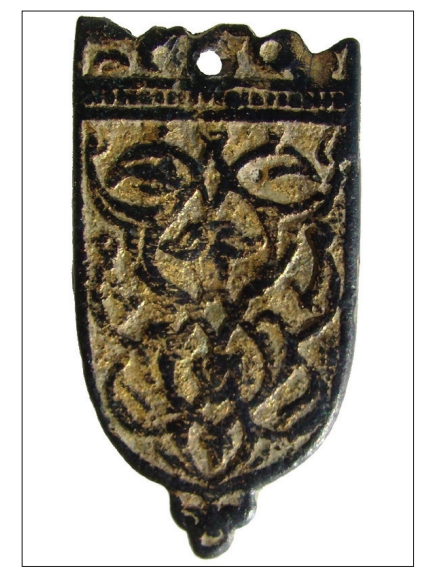

Slika 14. Ostrovica, slučajni nalaz pojasnog jezičca (snimio Mato Ilkić)

Nažalost, nije nam poznat točan položaj nalaza jezičca iz Ostrovice, ali, uz dužan oprez, možemo pretpostaviti kako je možda izvorno bio u inventaru pokojnika pokopanog s parom ranokarolinških ostruga u zidanoj grobnici na položaju Greblje. Zbog nepoznatog arheološkog konteksta toga dragocjenog nalaza, ne treba se upuštati u daljnja nagađanja. Već pronalaženje toga dragocjenog ranokarolinškog nalaza predstavlja dopunu slike o razdoblju koje u svojem uratku nastojimo upotpuniti novim spoznajama.

Ostrovica je markantan i strateški važan položaj koji je u razdoblju od prapovijesti do kasnoga srednjeg i ranoga novog vijeka bio nezaobilazan. Taj položaj bio je svakako važan, ponajprije zbog nadzora kopnenih prometnih pravaca iz

62 Leksikon ikonografije, liturgike i simbolike zapadnog kršćanstva. 2006, 147 (Arbor vitae), AB.

63 Koristimo prigodu da ujedno zahvalimo i kolegi doc. dr. sc. Mati Ilkiću, koji nas je upozorio na taj dragocjeni nalaz iz Ostrovice. 
kontinentalne unutrašnjosti prema istočnoj jadranskoj obali. Ta je važnost svakako prepoznata i u ranom srednjovjekovlju.

\section{Biskupija - Sv. Marija, Crkvina (kamena plastika)}

$\mathrm{U}$ početcima rađanja zanimanja za hrvatski rani srednji vijek $\mathrm{u}$ fokusu arheoloških istraživanja bili su ostatci crkve sv. Marije na položaju Crkvina u selu Biskupija kraj Knina. Tijekom ranih arheoloških istraživanja toga najvažnijeg nalazišta iz karolinškog razdoblja u Hrvatskoj, koja su otpočela 1886. godine, otkriven je u „... zgradama, koje su uz baziliku...” vrlo zanimljiv ulomak stupića od vapnenca koji je prvi objavio Frano Radić, jedan od pionira hrvatske arheologije ranoga srednjeg vijeka. ${ }^{64}$ Posebnost tog stupića jest $\mathrm{u}$ ukrašenoj prednjoj plohi na kojoj je prikaz zmaja s rogom koji izlazi iz glave mitske životinje i u troprutoj traci pletera koji izlazi iz otvorenih ralja te završava u repu zvijeri (slika 15). Detaljne opise susrećemo kod niza autora koji su analizirali taj spomenik i pokušali mu očitati vrijeme postanka u širokom rasponu 8./9. - 11. stoljeća. ${ }^{65}$

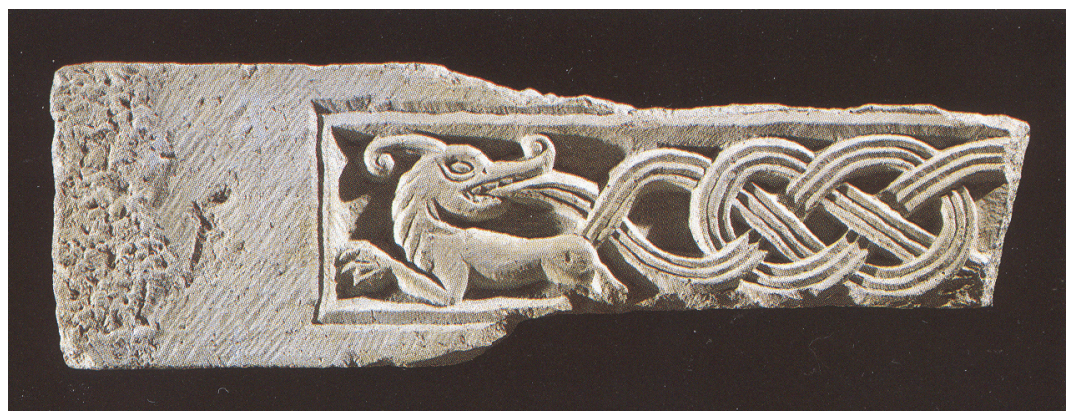

Slika 15. Sv. Marija Crkvina u selu Biskupija kraj Knina, ulomak stupića s prikazom zmaja (MILOŠEVIĆ 2000, 2, 205, IV. 31)

Uzimajući u obzir opsežan osvrt V. Bierbrauera na rijetke uščuvane ranosrednjovjekovne liturgijske predmete iz Bavarske i susjednih alpskih regija, poput relikvijara-burse iz katedralnog blaga u Churu te ulomaka pluteja oltarnih

$\overline{64}$ RADIĆ, Frano 1895. - Nekoliko ulomaka lezena, pluteja, vratnih pragova i lukova sa starohrvatske bazilike sv. Marije u Biskupiji kod Knina. Starohrv.Prosvj., 1/1895.

65 RADIĆ 1895; KARAMAN 1930; PETRICIOLI 1960, 63; GUNJAČA, JELOVINA, GRČEVIĆ 1976, 102 (opis nalaza), 44, sl. 29 - Ulomak stupića iz Biskupije kraj Knina. Vis. 0,64 m, šir. 0,19 m. MHAS; MILOŠEVIĆ 2000, 2, 205, kat. IV. 31. 
pregrada iz samostana Müstair, ${ }^{66}$ primijećeno je ne samo preuzimanje utjecaja s atlantskih rubova Europe ${ }^{67}$ slijedom irsko-anglosaksonske misije u istočni dio Karolinškoga Kraljevstva pristiglog novog anglo-karolinškog animalnog stila, ${ }^{68}$ već $\mathrm{k}$ tome i njegova povezivanja s autohtonim, kasnoantičko-mediteranskim umjetničkim stvaralaštvom. ${ }^{69}$ Umjetnici s alpskog prostora bili su upoznati s novim umjetničkim izrazom, ali i s tradicijom nasljeđa, što je omogućilo prepoznavanje potencijalnog prostora nastanka relikvijara Chur - St. Gallen. S jedne su strane u samostanu Müstair, koji je osnovao churski biskup, $\mathrm{u}$ istom stilu ukrašeni ulomci pluteja oltarnih pregrada, dok je s druge strane, kao što je poznato, bio St. Gallen kao važno misionarsko središte - jedan od najvažnijih posrednika inzularne umjetnosti, a sve to na podlozi daljnjeg živućeg autohtonog, umjetničkog stvaralaštva mediteranskog izričaja. ${ }^{70}$ Relikvijar-bursu iz Chura i fragmente pluteja oltarne pregrade iz Müstaira Bierbrauer datira u posljednju četvrtinu 8 . stoljeća. ${ }^{71}$

Spomenute analogije s velikom stilskom sličnosti na plutejima oltarnih pregrada iz samostana u Müstairu navele su Miloševića na pomisao o stilskom povezivanju stupića iz Sv. Marije na položaju Crkvina u Biskupiji kraj Knina s prikazom zmaja i troprutastog pletera u kojem se vrlo jasno prepoznaje animalni stil inzularne umjetnosti kontinentalnih karakteristika, primjeren svršetku 8. ili neposrednom početku 9. stoljeća. ${ }^{72}$

Nalaz stupića iz nekog nama nepoznatog objekta, zacijelo starijeg od crkve sv. Marije u Biskupiji kraj Knina, uz koju je pronađen, upućuje na umjetnički stil Tassilova kaleža, kojemu je kulturni izraz prepoznat u ishodišnom alpskom prostoru, ali i u južnim i istočnim regijama.

\footnotetext{
66 Benediktinsku opatiju sv. Ivana u Müstairu u pokrajini Graubünden u Švicarskoj osnovao je potkraj 8. stoljeća churski biskup, odnosno, prema predaji, Karlo Veliki.

67 ANDREWS 2003, 4.

68 BIERBRAUER 1988, 329, sl. 218, 330, sl. 219, bilj. 8. O nastupu irsko-anglosaksonskog animalnog stila usporedi relevantnu literaturu koju navodi BIERBRAUER 1988, 340, bilj. 7.

69 BIERBRAUER 1988, 329.

70 BIERBRAUER 1988, 329.

71 MILOŠEVIĆ 2000, 2, 205-206, kat. IV. 31.

72 MILOŠEVIĆ 2000, 2, 206.
} 


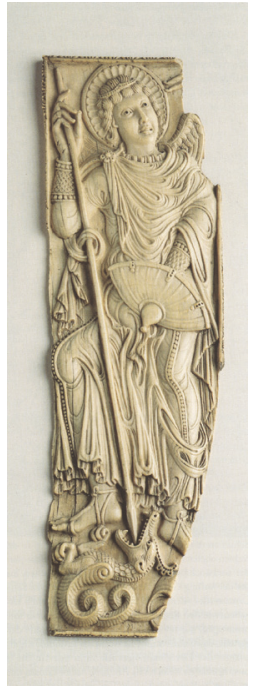

Slika 16. Arkanđeo Mihovil u boju sa zmajem (prema 799 Kunst und Kultur 1999, 2, X.30)

U osvrtu na nalaz prikaza zmaja na stupiću iz Biskupije kraj Knina upozoravamo na zanimljivu analogiju koju, s obzirom na izgled glave s roščićem, nalazimo na diptihu od bjelokosti s prikazom arkanđela Mihovila, koji kopljem probada ralje zvijeri (slika 16). ${ }^{73}$ Taj je dragocjeni nalaz diptiha zapadnorimskog konzula iz 5. stoljeća sekundarno upotrijebljen početkom 9. stoljeća za potrebe dvorske škole Karla Velikog. Vjerojatno je riječ o prikazu apokaliptičnog boja, pa u tom smislu valja pokušati spoznati i biskupijski prikaz zmaja - oličenja zla, koje je u vječnom sukobu sa silama dobroga (tropruti pleter vinove loze). Taj zmaj s pleterom, tj. mitski Oùrobórus s Crkvine, simbolički je prikaz besmrtnosti ili obračuna kršćanstva s poganstvom. Relikt je franačke misionarske djelatnosti potkraj 8. stoljeća i u prvom desetljeću 9. stoljeću iz eklezijastičkog središta u Akvileji. Svojom naglašeno visokom kvalitetom klesarske izrade životinjskog lika zmaja, upletenog u tropruti pleter, jasno nas upućuje na neku od majstorskih klesarskih radionica u Akvileji ili možda čak u Zadru. ${ }^{74}$

\section{Stara Vrlika - Runjavica (kadionica)}

Na položaju Runjavica na izvoru rijeke Cetine kraj Stare Vrlike, u nepoznatim uvjetima i kontekstu, otkrivena je 1925. godine jedinstvena kadionica od lijevanog srebra, pozlaćena i s niello ukrasima (slika 17), koju je podrobno obradila i znanosti prvi put približila Ksenija Vinski-Gasparini. ${ }^{75}$ Tom je prigodom taj unikatni nalaz logično povezala s bavarskim umjetničkoobrtnim radionicama ranoga karolinškog doba u Salzburgu, za biskupovanja Virgilija (745. - 784.), podrijetlom Irca (Fergal), čija je sveza s njegovom domovinom povijesno potvrđena $\mathrm{i}$ bez obzira na inače poznati utjecaj inzularne umjetnosti na kontinent $u$ karolinško doba. ${ }^{76}$

\footnotetext{
73 JÜLICH 1999, 2, 747-748, kat. X. 30. Nalaz je pohranjen u Muzeju za umjetnički obrt u Leipzigu.

74 TOMIČIĆ 2016, 122.

75 VINSKI-GASPARINI 1958, 93-104.

76 VINSKI-GASPARINI 1958, bilj. 17.
} 


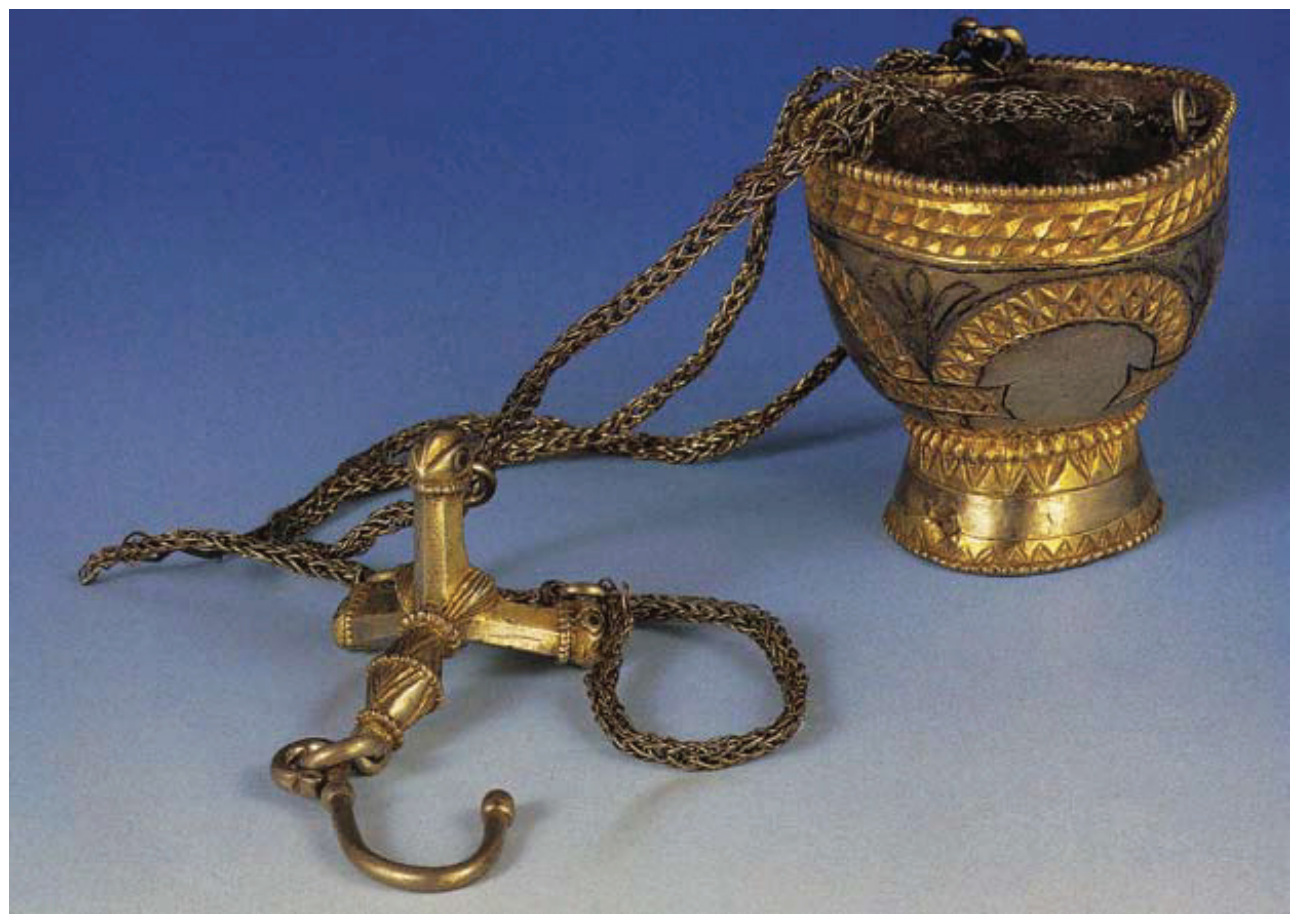

Slika 17. Kadionica iz Cetine kraj Vrlike, Runjavica (MILOŠEVIĆ 2000, 2, IV. 119)

Kadionica je dospjela u dalmatinsku Zagoru karolinškim posredovanjem, pa je, prema uvjerenju K. Vinski-Gasparini, terminus ante quem non njezine pojave u tom kraju 803. godina, iz kojeg vremena potječe i srebrni relikvijar franačkog sveca Asela u Ninu. ${ }^{77}$ Kadionica je doista jedinstveni liturgijski predmet $\mathrm{u}$ sveukupnom nasljeđu Karolinga, a osnovnim oblikom, kompozicijom ukrasa, tehnikom dubokog rovašenja i kolorističkim efektom (niello) najsrodnija je Tassilovu kaležu, pa je pripisana tzv. stilu Tassilova kaleža. ${ }^{78}$ Pritom svakako valja u obzir uzeti i moguće utjecaje sjevernoitalskih radionica koje gaje klasične mediteranske tradicije. ${ }^{79}$ Prema toj analizi, kadionica je u Zagoru mogla dospjeti u posljednjoj četvrtini 8 . ili početkom 9. stoljeća, ${ }^{80}$ što nije u suprotnosti sa sta-

\footnotetext{
77 VINSKI-GASPARINI 1958, 101, bilj. 34; KARAMAN 1941/1942, 111; KARAMAN 1943, 134. Novija datiranja relikvijara sv. Asela iz Nina stavljaju taj nalaz u prvu polovinu 9. stoljeća (vidi: MILOŠEVIĆ 2000, 2, 288-289; usporedi priloženu literaturu). 
vom iznesenim prigodom prvog objavljivanja tog remek-djela ranokarolinškoga kulturnog kruga, ${ }^{81}$ a ujedno je svjedočanstvo organizirane i snažne misionarske djelatnosti te uvođenja franačke crkvene liturgije nakon okončanja ratova s Avarskim Kaganatom. ${ }^{82}$

\section{Zaključna razmatranja}

Nakon uspješnog okončanja rata s Avarima 796., odnosno 803. godine, Franci su ostvarili velike uspjehe, ali su ujedno postavili i vrlo zahtjevne zadatke intenzivne misionarske djelatnosti i pokrštavanja brojnog puka na novoosvojenim područjima od Alpa do Dunava i istočnojadranskog obalnog ruba s pripadajućim arhipelagom na kojima su bila stara urbana središta života. Tome valja pridružiti i rastući državni interes Franačkog Carstva u kojem je jedinstvena vjera imala bitan državotvorni utjecaj, posredovanjem Crkve, koja je bila potpuno ovisna o Karlu Velikom. Crkva je neposredno poticala i proces feudalizacije.

Kada su se u granicama iste države otvorila nova, velika područja misionarske djelatnosti, nastupio je prijelomni trenutak u kojem je znatan doprinos dao opat Alkuin iz Yorka, savjetnik Karla Velikog, usmjeravajući jedinstvenu misionarsku djelatnost među zatečenim stanovništvom, zajedno s nadbiskupom Salzburga Arnom i akvilejskim patrijarhom Paulinom II. To je bilo djelo primjene nenasilnog djelovanja irskih monaha i salzburških biskupa. ${ }^{83}$

Nakon sastanka italskoga kralja Pipina te nadbiskupa Arna pod koncilijarnim vodstvom akvilejskog patrijarha Paulina II. u franačkom vojnom logoru na obali Dunava 796. godine, uslijedio je dogovoreni način misionarske djelatnosti. ${ }^{84}$ Ujedno je dogovoreno da rijeka Drava postaje granicom djelovanja Salzburške nadbiskupije i Akvilejskog patrijarhata, što je 803. i 811. godine potvrdio osobno i car Karlo Veliki.

Na priloženom zemljovidu (slika 4) označeni su položaji nalaza inzularne umjetnosti, poglavito predmeti ratničke opreme, nastali prema oblikovnom kanonu stila Tassilova kaleža. Riječ je o nalazima pojasnih jezičaca iz: Tonovcova grada kraj Kobarida, Sipara u Istri, Medvedičke u Podravini, Gornjih Vrbljana na Sani i Mogorjela kraj Čapljine na rijeci Neretvi na kojima se jasno razabire kombinacija animalnih s florealnim ukrasima. U toj skupini svakako treba izdvojiti, kao umjetničkoobrtne izrađevine najviše razine, dugi pojasni jezičac iz kastru-

\footnotetext{
81 VINSKI-GASPARINI 1958, 93-104.

82 MILOŠEVIĆ 2000, 2, 253.

83 SZŐKE 2009.

84 TOMIČIĆ 2013, 53-70.
} 
ma u Gornjim Vrbljanima iznad izvora rijeke Sane (slike 10.a, 10.b), odnosno pojasnu garnituru iz kastela Mogorjelo kraj Čapljine uz desnu obalu rijeke Neretve (slika 11). To su posebno kvalitetni umjetničkoobrtni objekti koji su poslužili kao sastavni dijelovi opreme visokorangiranih karolinških ratnika, a ujedno predstavljaju i svjedočanstva o duhovnoj opredijeljenosti gornjeg vojničkog sloja franačkog društva. Naime, primijećeno je da su se objekti s ukrasima inzularne umjetnosti u stilu Tassilova kaleža pronašli na strateški važnim mjestima, poglavito uz planinske prijevoje (Tonovcov grad) i riječne tokove (Sane i Neretve), dakle uz pogodne prometne pravce uz koje su ti odličnici bili stacionirani u uporištima. S tih istaknutih položaja na kojima dijelove ratničke opreme susrećemo kao relikte iz sukoba s poganskim pukom (Gornji Vrbljani), odnosno u mogućem grobnom kontekstu (Mogorjelo), ostvarivali su zadatke proširivanja i očuvanja vjere. Nalaz pojasnog jezičca iz Medvedičke, ukrašenog u stilu Tassilova kaleža, uz ostali grobni inventar pripadao je također istaknutom ratniku koji je možda povezan s franačkim ratnim pohodom podravskim pravcem prema desnoj obali Dunava tijekom 795. i 796. godine ${ }^{85}$ Nalaz pojasnog jezičca s animalnim ukrasom, otkriven u kastelu Sipar na zapadnoj obali Istre, može se svakako datirati nakon 788. godine, tj. do svršetka 8. stoljeća. I taj dragocjeni relikt može se pouzdano pripisati stilu Tassilova kaleža. Konačno, tom kulturnom krugu inzularne umjetnosti pripisujemo i ulomak stupića s prikazom zmaja i troprutog pletera s položaja Crkvina kraj Sv. Marije u Biskupiji kraj Knina (slika 15).

Osim nalaza koji predstavljaju svjedočanstva neposrednijeg utjecaja, poglavito irske misionarske djelatnosti iz alpskoga kruga, tj. iz „inzularne kulturne provincije" u doba Karla Velikog, na promatranom prostoru do Dunava i Neretve te zaobalja istočnojadranskog pročelja susrećemo i ranokarolinške nalaze $\mathrm{u}$ kojima se prepoznaje tradicionalni, klasični mediteranski umjetnički izraz. U tom klasičnom, mediteranskom izričaju prevladavaju florealni ukrasi poput duboreznih palmeta, rozeta, vitica vinove loze ili ponekad motiv Drveta života. Riječ je o nalazima pojasnih jezičaca s ukrasima vitica i duboreznih palmeta s nalazišta na alpskom prijevoju Gradišče nad Sotesko (slika 6) i sličnog u Mogorjelu kraj Čapljine (slika 12) u blizini riječnog prijelaza na Neretvi. Nalaz pojasnog jezičca ukrašenog viticama vinove loze, pronađen na položaju kasteluma Cornacum, tj. u današnjem Sotinu (slika 13), nastojimo povezati s franačkim vojnim pohodom italskoga kralja Pipina 796. na desnu obalu Dunava poradi uništenja Avarskog Kaganata. ${ }^{86}$ Zasebno mjesto svakako pripada nalazu pojasnog jezičca

\footnotetext{
85 TOMIČIĆ 2012 .

86 TOMIČIĆ 2012, 153, sl. 10; SIMONI 2000, Arheološka slika ranog srednjovjekovlja na prostoru međurječja Drave, Dunava i Save, u: HRVATI I KAROLINZI, Rasprave, 153, sl. 10.
} 
s motivom Drveta života, pronađenom u Ostrovici (slika 14), dakle također na strateški nezaobilaznoj točki na ulazu u istočnojadransko zaobalje.

Naposljetku, prigodom razmatranja unikatnog liturgijskog predmeta kakvim se predstavlja kadionica iz Stare Vrlike - Runjavice kraj sela Cetine (slika 17), a pri kojem svakako valja u obzir uzeti i moguće utjecaje sjevernoitalskih radionica koje su gajile klasične mediteranske tradicije, ${ }^{87}$ na neki način zaokružujemo repertoar ranokarolinške nazočnosti na prostoru obuhvaćenom naslovom našeg rada.

Sva je prigoda da su sumarno prikazani primjerci tzv. inzularne umjetnosti nastali kao svjedočanstva stila Tassilova kaleža, kao i oni oblikovani pod snažnim klasičnim mediteranskim tradicijama, jasan odraz organiziranog nastupa Franaka uoči i tijekom, a posebice nakon uništenja Avarskoga Kaganata. Uklanjanjem Avara s europske političke scene stvorene su jasne pretpostavke za široko administrativno i vjersko organiziranje novopripojenog prostora od Alpa do Dunava i Neretve, odnosno do istočnojadranskog oboda. Time je pružena potpora vazalnim slavenskim gentilnim kneževinama i ostatcima otprije prisutnog stanovništva (Avara), u ogromnom međuprostoru od Dunava na sjeveru do zaobalja istočne obale Jadrana na jugu, da se integriraju u Franačko Carstvo. Taj proces misionarske djelatnosti, pokrštavanja pučanstva te crkvenog i administrativnog organiziranja odvijao se u razdoblju od uništenja Avarskoga Kaganata 796., odnosno konačno 803., do zaključenja mira u Aachenu 812. godine. $\mathrm{Ne}$ treba smetnuti s uma ni činjenicu da je tadašnja druga europska sila - Bizantsko Carstvo - s kojom je u doba vladavine cara Mihajla I. Rangabe zaključen Aachenski mir, s obzirom na talasokraciju i ambicije, uspjela ugovorno zadržati nisku urbanih aglomeracija na arhipelagu i priobalju istočne obale Jadrana. Te su urbane jezgre bile u neprekinutom kontinuitetu jedan od bitnih činitelja sveukupnog oblikovanja jedinstvene kulturne dinamike u prostoru obuhvaćenom naslovom rada.

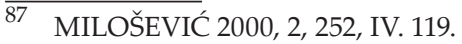




\section{Popis Literature}

ANDREWS 2003 - John H. ANDREWS, Pogled geografa na irsku povijest, u: POVIJEST IRSKE uredili Theodore William Moody, Francis Xavier Martin, Zagreb 2003, 1-12.

BIERBRAUER 1988 - Volker BIERBRAUER, Liturgische Gerätschaften aus Baiern und seinen Nachbarregionen in Spätantike und frühem Mittelalter, in: DIE BAJUWAREN Von Severin bis Tassilo 488 - 788 (Red.: Hermann DANHEIMER, Heinz DOPSCH), Rosenheim, Salzburg 1988., Abb. 219: Müstair.

BITENC, KNIFIC 2001 - Polona BITENC, Timotej KNIFIC (ur.), Od Rimljanov do Slovanov, Predmeti (ur.), Ljubljana 2001.

BOJANOVSKI 1974 - Ivo BOJANOVSKI, Ranosrednjovjekovno utvrđenje u Vrbljanima na Sani. Glas.Zem.Muz.Arheol., n.s. 29/1974, 245-255.

BOJANOVSKI 1979 - Ivo BOJANOVSKI, Kasnoantički kaštel u Gornjim Vrbljanima na Sani.Glas.Zem.Muz.Arheol., n.s., 34/1979, 105-125.

CIGLENEČKI 1994 - Slavko CIGLENEČKI, Poznoantička naselbina Tonovcov grad pri Kobaridu, Kronika 42, Ljubljana 1994, 1-14.

DELONGA 2000 - Vedrana DELONGA, Pismenost karolinškog doba i njeni hrvatski odjeci - latinska epigrafička baština u hrvatskim krajevima, HRVATI I KAROLINZI, 1, 242 (kat. br. IV, 131).

ELBERN 1989 - Victor H. ELBERN , Heilige, Dämonen und Magie an Reliquiaren des frühen Mittelalters, in: Santi e demoni nell alto Medioevo occidentale (secole V-XI) (Settimane di studio del centro italiano di studi sull alto medioevo 36), Spoleto 1989, 951-980.

GREWE 1999 - Holger GREWE, Riemenzunge aus Ingelheim, 465-466, Katalog VII.27, in: 799 Kunst und Kultur der Karolingerzeit. Karl der Große und Papst Leo III. in Paderborn, Band 2, Katalog der Austellung Paderborn 1999.

GUNJAČA, JELOVINA, GRČEVIĆ 1976 - Stjepan GUNJAČA, Dušan JELOVINA, Mladen GRČEVIĆ, STAROHRVATSKA BAŠTINA, Zagreb 1976,

HASELOFF 1951 - Günther HASELOFF, Der Tassilokelch. MünchBeitr 1, 1951.

HASELOFF 1981 - Günther HASELOFF, Die frühmittelalterlichen Chorschrankenfragmente in Müstair, in: Helvetia Arch. 41, 1981, S. 21 ff.

ILKIĆ 2007 - Mato ILKIĆ, Nalazi seobe naroda i ranoga srednjeg vijeka iz Sotina [Funde der Völkerwanderung und des Frühmittelalters aus Sotin], Pril.Inst.Arheol.Zagrebu, 24/2007, 277-288.

JÜLICH 1999 - Theo JÜLICH, Erzengel Michael, 747-748, kat. X. 30., Renovatio in Kunst und Wissenschaft, in: Kunst und Kultur der Karolingerzeit. 799 Karl der Große und Papst Leo III. in Paderborn, Band 2. Katalog der Ausstellung Paderborn $1999,2$. 
KARAMAN 1930 - Ljubo KARAMAN, Iz kolijevke hrvatske prošlosti, Zagreb 1930.

KARAMAN 1941/42 - Ljubo KARAMAN, Spomenici VII. i VIII. stoljeća u Dalmaciji, VHAD, n. s. XXII-XXIII, Zagreb, 1941/42, 111.

KARAMAN 1943 - Ljubo KARAMAN, Živa starina, Zagreb, 1943, 134.

MARUŠIĆ 1973-1975 - Branko MARUŠIĆ, Neki problemi kasnoantičke i bizantske Istre, Jadranski zbornik, 1973-1975, 9.

MARUŠIĆ 1995 - Branko MARUŠIĆ et al. Istra i sjevernojadranski prostor u ranom srednjem vijeku: (materijalna kultura od 7. do 11. stoljeća) [L'Istrie et l'Adriatique septentrional a l'epoque du haut Moyen age: (la culture materielle du VIIe a le XIe siecle], Arheološki muzej Istre, Monografije i katalozi, 4, Pula, 1995, 113 (kat. jed. 489. Sipar, pojasni jezičac).

MATIJAŠIĆ 2008 - Robert MATIJAŠIĆ, Istarska enciklopedija, Sipar, Pula 2008.

McKITTERICK 2005 - Rosamond McKITTERICK, THE CAROLINGIAN RENAISSANCE OF CULTURE AND LEARNING, in CHARLEMAGNE EMPIRE AND SOCIETY (edited by Joanna Story), Manchester 2005, 151-166.

MILETIĆ 1963 - Nada MILETIĆ, Nakit i oružje IX-XII veka u nekropolama Bosne i Hercegovine, Glasn.Zem.Muz., 18/ 1963, 156, Sl. 1,b i c.

MILOŠEVIĆ 2000 - Ante MILOŠEVIĆ, HRVATI I KAROLINZI, Katalog, 205-206, kat. IV. 31.

PATSCH 1911 - Carl PATSCH, Bosnien und Hercegowina in römischer Zeit, Sarajevo, 1911, 15.

PETRICIOLI 1960 - Ivo PETRICIOLI, Pojava romaničke skulpture u Dalmaciji, Zagreb, 1960.

RADIĆ 1895 - Frano RADIĆ, Nekoliko ulomaka lezena, pluteja, vratnih pragova i lukova sa starohrvatske bazilike Sv. Marije u Biskupiji kod Knina, ShP I br. 3, Knin 1895.

RAUKAR 1997 - Tomislav RAUKAR, Hrvatsko srednjovjekovlje, Počeci političkog organiziranja, Školska knjiga, Zagreb 1997, 24.

SIMONI 2000 - Katica SIMONI, Medvedička kraj Đurđevca: u HRVATI I KAROLINZI, Katalog, 92-93, kat.br. II. 15.

SCHULZE-DÖRRLAMM 2009 - Mechthild SCHULZE-DÖRRLAMM, GEGOSSENE GÜRTEL- UND RIEMENBESCHLÄGE MIT KAROLINGISCHEM PFLANZENDEKOR AUS ANDALUSIEN. JRGZM, Jahrbuch des Römisch-Germanischen Zentralmuseums Mainz 56. Jahrgang 2009, 743-788, Karta rasprostiranja Abb. 28 i Popis nalaza 26.

SZŐKE 2009 - Béla Miklós SZŐKE, Karolingische Kirchenorganisation in Pannonien, in GLAUBE, KULT UND HERRSCHAFT, Phänomene des Religiösen im 1. Jahrtausend n. Chr. in Mittel- und Nordeuropa, FRANKFURT A. M. EURASIEN ABTEILUNG, BERLIN des Deutschen Archäologischen Instituts, Kolloquien zur Vor- und Frühgeschichte Band 12, Bonn, 2009, 395-416. 
SZŐKE 2011 - Béla Miklós SZŐKE, DIE DONAU UND DIE LETZTEN TAGE DES AWARISCHEN KHAGANATS, VAH XXVI, 265-294.

TOMIČIĆ 2000 - Željko TOMIČIĆ, Arheološka slika ranog srednjovjekovlja na prostoru međuriječja Drave, Dunava i Save, u: HRVATI I KAROLINZI, Rasprave, 153, sl. 10.

TOMIČIĆ 2012 - Željko TOMIČIĆ, Castra...super flumen albidum Danubium. - O položaju avarske utvrde iz Lorških Anala.RAD HRVATSKE AKADEMIJE ZNANOSTI I UMJETNOSTI, RAZRED ZA DRUŠTVENE ZNANOSTI KNJIGA 50=516, Zagreb 2013, 53-70.

TOMIČIĆ 2016 - Željko TOMIČIĆ, Predromanički ulomak sa životinjskim likom iz Crkvine u Biskupiji kraj Knina. Prinos mogućim utjecajima inzularne umjetnosti. Rad Hrvatske akademije znanosti i umjetnosti. Razred za društvene znanosti 51 = 525, 107-125.

UGLEŠIĆ 1994 - Ante UGLEŠIĆ, Nalazi seobe naroda iz zbirke Mate Ilkića, RFFZd 33 (20) (1993-1994), Zadar, 145-152.

UJČIĆ 2000 - Željko UJČIĆ, Hrvati i Karolinzi, Katalog, Split 2000, 71, I. 61.

VINSKI-GASPARINI 1958 - Ksenija VINSKI-GASPARINI, Ranosrednjovjekovna kadionica iz Stare Vrlike, ShP, sv. 6, Split, 1958, 93-104

VINSKI 1977/1978 - Zdenko VINSKI, Frühkarolingische Neufunde in Jugoslawien, in: VAMZ 10-11, Zagreb 1977/1978, 190-208.

VINSKI 1983 - Zdenko VINSKI, Zu karolingischen Schwertfunden aus Jugoslawien. JRGZ, 30, 1983.

VINSKI 1985-Zdenko VINSKI, Marginalia uz izbor karolinškog oružja u jugoistočnoj Evropi, ShP 15, 62. Mogorjelo, b. 3; Sl. 1, 2, 3;

WAMERS 1999 - Egon WAMERS, Insulare Kunst im Reich Karls des Großen. In: 799 Kunst und Kultur der Karolingerzeit Karl der Große und Papst Leo III. in Paderborn, Mainz 1999, 454-464.

WERNER 1959 - Joachim WERNER, Frühkarolingische Silberohrringe von Rastede (Oldenburg). Beiträge zur Tierornamentik des Tassilokelches und verwandter Denkmäler. Germania 37.

WERNER 1961 - Joachim WERNER, Ranokarolinška pojasna garnitura iz Mogorjela kod Čapljine (Hercegovina). [Frühkarolingische Gürtelgarnitur aus Mogorjelo bei Čapljina (Hercegovina)], GZMS 1961, 235-247.

ZEKAN 1994 - Mate ZEKAN, Karolinški i poslijekarolinški nalazi iz Bosne i Hercegovine. In: Livanjski kraj u povijesti. Split-Livno, 1994, 55 -73. 


\section{Popis skraćenica}

Germania

Glas.Zem.Muz.Arheol

Helvetia Arch

HRVATI I KAROLINZI

JRGZM

MünchBeitr

Pril.Inst.Arheol.Zagrebu

RFFZd

ShP

VAH

VHAD
Anzeiger der Römisch-Germanischen Kommission des Deutschen Arhäologischen Instituts, Frankfurt a/Main

Glasnik Zemaljskog muzeja Sarajevo (Arheologija), Sarajevo

Helvetia Archaeologica

HRVATI I KAROLINZI, Dio prvi Rasprave i vrela, Dio drugi Katalog, Split

Jahrbuch des Römisch-Germanischen Zentralmuseums, Mainz

Münchner Beiträge zur Vor- u. Frühgeschichte, München

Prilozi Instituta za arheologiju u Zagrebu, Zagreb

Radovi Filozofskog fakulteta u Zadru, Zadar

Starohrvatska prosvjeta, Knin; n.s., Knin-Zagreb, ser. 3, Split

Varia Archaeologica Hungarica, Budapest

Vjesnik Hrvatskog arheološkog društva, nova serija, 1895 


\section{Summary}

\section{The Area from the Alps and the Adriatic to the Rivers Danube and Neretva in the Light of Material Traces of the Carolingian Insular Art}

An episode with the findings of the insular Irish, Anglo-Saxon, or generally Hiberno-Carolingian art represents a specific theme within the cultural history of the European Early Middle Ages. It was associated with missionary activity, and could not bypass the areas from the Alps and the Adriatic to the rivers Neretva and Danube, especially not in the historical moments that preceded the Treaty of Aachen, signed in 812 between Emperor Charlemagne (768-814) and the Byzantine Emperor Michael I. Rhangabe (811-813).

After the successful end of the war with the Avars in the battles of the years 796 and 803, the Franks became outstandingly strong, but were at the same time confronted with very demanding tasks of intensive missionary activity, and the baptism of numerous people in the newly conquered areas from the Alps to the Danube and the Eastern Adriatic coast with the associated archipelago and its old urban centres. A growing political interest of the Frankish Empire should be added thereto; therein, the official religion exerted a significant state-forming influence through the mediation of the Church, which was entirely dependent on Charlemagne. The process of feudalisation was also directly encouraged by the Church.

When new, large areas of missionary activity opened up within the borders of the same state, a landmark moment occurred; a significant contribution thereto was made by Abbot Alcuin of York, adviser to Charlemagne, directing a coordinated missionary activity among the affected population, together with Archbishop Arn of Salzburg and Patriarch Pauline II of Aquileia. Ultimately, it was the achievement of applying a non-violent strategy of the Irish monks and the bishops of Salzburg.

After a meeting between the Italian King Pepin and Archbishop Arn under the conciliar guidance of Patriarch Pauline II of Aquileia in the Frankish military camp on the banks of Danube in 796, an agreed manner of missionary activity followed. It was further agreed that the Drava River would become the boundary between the Diocese of Salzburg and the Patriarchate of Aquileia, which was confirmed by Emperor Charlemagne personally in 803 and 811.

The enclosed map (Fig. 4) shows the positions of the insular art finds, in particular items of warrior equipment based on the model of the Tassilo chalice style. These are the finds of belt tongues from Tonovcev grad near Kobarid, Sipar in Istria, Medvedička in Podravina, Gornji Vrbljani on the Sana River, and Mogorjelo near Čapljina on the Neretva River, where a combination of zoomorphic and floral ornaments is clearly perceived. Two finds from this group should be pointed out as distinguished examples of excellent workmanship. The first one is a long belt tongue from the castrum in Gornji Vrbljani above the source of the Sana River, while the second is a belt from the Mogorjelo Castel near Čapljina along the right bank of the Neretva River. These are exceptional high-quality art and craft artefacts, which were an integral part of the equipment of high-ranking Carolingian warriors, illustrating at the same time the spiritual commitment of the upper military class of the Frankish society. It 
was noticed that the objects with the insular art decorations of the Tassilo chalice style were found in strategically important places, in particular along mountain passes (Tonovcov grad) and river courses (Sana and Neretva), i.e. along convenient traffic routes, on which these dignitaries were stationed in various strongholds. From these prominent positions, where we encounter pieces of warrior equipment as relics from conflicts with the pagan population (Gornji Vrbljani) or potentially in burial context (Mogorjelo), they accomplished the tasks of expanding and preserving religion. The Medvedička belt tongue, decorated in the style of the Tassilo chalice, along with the remainder of the grave inventory in question, was also in the possession of a prominent warrior, who may have been associated with the Frankish march in the direction of Podravina, towards the right bank of the Danube in 795 and 796. The find of the belt tongue with an animal ornament, discovered in the Sipar Castel on the western coast of Istria, may with certainty be dated between 788 and the end of the $8^{\text {th }}$ century, and it may with confidence be attributed to the style of the Tassilo chalice. Finally, a fragment of a column depicting a dragon and a triple interlace decoration, originating from the site of Crkvina near the Church of St. Mary in Biskupija near the town of Knin, may be attributed to the same cultural circle of insular art.

In addition to the finds bearing witness to a more direct influence, especially of the Irish missionary activity from the Alpine Circle, i.e. from the "insular cultural province" in the time of Charlemagne, the area of study (between the Danube and Neretva Rivers and along the immediate hinterland of the Eastern Adriatic coast) also witnessed early Carolingian finds that reveal traditional, classic Mediterranean artistic expressions. In this classic Mediterranean style, floral ornaments predominate: wood-cut palm trees, rosettes, vines, or sometimes the Tree of Life motif. Among these are belt tongues with ornaments of tendrils and wood-cut palm trees from the site on the Alpine pass Gradišče nad Sotesko, and a similar one from Mogorjelo near Čapljina, in the vicinity of the crossing on the Neretva River. A belt tongue decorated with vine tendrils found at the position of the castellum Cornacum (present-day Sotin) should be connected with the Frankish military march of the Italian King Pepin to the right bank of the Danube, aimed at bringing to destruction the Avar Khaganate in 796. A special place undoubtedly belongs to a belt tongue with the motif of the Tree of Life found in Ostrovica, i.e. at yet another strategically unavoidable point at the entrance to the Eastern Adriatic coast.

Finally, when looking at a unique liturgical object, such as the censer from Stara Vrlika-Runjavica near the village of Cetina, which certainly reflects possible influences of the Northern Italian workshops that cultivated classical Mediterranean traditions, in a way we round out the repertoire of the early Carolingian presence in the area of our interest here.

There is every reason to believe that the summarily addressed specimens of the so-called insular art, created as testimonials to the style of the Tassilo chalice, as well as those shaped under strong classic Mediterranean traditions, clearly reflect the organized appearance of the Franks before, during, and particularly after the destruction of the Avar Khaganate. The removal of the Avars from the European political scene created sound conditions for a wide administrative and religious organization of the newly-acquired area from the 
Alps to the Danube and the Neretva, or to the Eastern Adriatic. This provided support to the vassal Slavic gentile principalities and the remaining Avar population in the vast interspace from the Danube in the north to the Eastern Adriatic coast in the south for integration into the Frankish Empire. This entire process of missionary activity, baptising of the population, and church and administrative organization, took place in the period from the destruction of the Avar Khaganate in 796, and finally in 803, until the conclusion of the peace in Aachen in 812. It should be remembered that the Byzantine Empire, the second strongest European power of the time, with which the Treaty of Aachen was signed in 812 during the reign of Michael I Rhangabe, managed - owing to its thalassocracy and ambitions - to stipulate a string of urban agglomerations along the Adriatic archipelago and its immediate hinterland. These towns have been a continuous factor of the creation of unique cultural dynamics in the territory covered by the title of this paper.

Keywords: The Treaty of Aachen; Charlemagne; Pepin; Avars; Salzburg; Aquileia; Pauline II; Irish missionary activity; finds of the island-art craftsmanship. 